\title{
A molecular physiological review of vegetative desiccation tolerance in the resurrection plant Xerophyta viscosa (Baker)
}

\author{
Jill M. Farrant ${ }^{1} \cdot$ Keren Cooper $^{1} \cdot$ Amelia Hilgart $^{1} \cdot$ Kamal O. Abdalla $^{2}$ \\ Joanne Bentley ${ }^{1} \cdot$ Jennifer A. Thomson $^{1} \cdot$ Halford J. W. Dace ${ }^{1} \cdot$ Nashied Peton $^{1}$. \\ Sagadevan G. Mundree ${ }^{3} \cdot$ Mohamed S. Rafudeen $^{1}$
}

Received: 4 January 2015 / Accepted: 5 May 2015/Published online: 22 May 2015

(C) The Author(s) 2015. This article is published with open access at Springerlink.com

\begin{abstract}
Main conclusion Provides a first comprehensive review of integrated physiological and molecular aspects of desiccation tolerance Xerophyta viscosa. A synopsis of biotechnological studies being undertaken to improve drought tolerance in maize is given.

Xerophyta viscosa (Baker) is a monocotyledonous resurrection plant from the family Vellociacea that occurs in summer-rainfall areas of South Africa, Lesotho and Swaziland. It inhabits rocky terrain in exposed grasslands and frequently experiences periods of water deficit. Being a resurrection plant it tolerates the loss of $95 \%$ of total cellular water, regaining full metabolic competency within 3 days of rehydration. In this paper, we review some of the molecular and physiological adaptations that occur during various stages of dehydration of $X$. viscosa, these being functionally grouped into early and late responses, which might be relevant to the attainment of desiccation tolerance. During early drying (to $55 \%$ RWC) photosynthesis is shut down, there is increased presence and activity of housekeeping antioxidants and a redirection of metabolism to the increased formation of sucrose and raffinose family
\end{abstract}

Special topic: Desiccation Biology.

Guest editors: Olivier Leprince and Julia Buitink.

Jill M. Farrant

jill.farrant@uct.ac.za

1 Department of Molecular and Cell Biology, University of Cape Town, Private Bag X3, Rondebosch 7701, South Africa

2 University of Gadarif,

P.O. Box 449, Gadarif 32211, Al Qadarif, Sudan

3 Queensland University of Technology, PO Box 2434, Brisbane, QLD 4001, Australia oligosaccharides. Other metabolic shifts suggest water replacement in vacuoles proposed to facilitate mechanical stabilization. Some regulatory processes observed include increased presence of a linker histone H1 variant, a Type 2C protein phosphatase, a calmodulin- and an ERD15-like protein. During the late stages of drying (to $10 \%$ RWC) there was increased expression of several proteins involved in signal transduction, and retroelements speculated to be instrumental in gene silencing. There was induction of antioxidants not typically found in desiccation-sensitive systems, classical stress-associated proteins (HSP and LEAs), proteins involved in structural stabilization and those associated with changes in various metabolite pools during drying. Metabolites accumulated in this stage are proposed, inter alia, to facilitate subcellular stabilization by vitrification process which can include glass- and ionic liquid formation.

Keywords Physiology - Proteome - Resurrection plant . Transcriptome $\cdot$ Vegetative desiccation tolerance

\author{
Abbreviation \\ ERD (LRD) Early (Late) response to desiccation
}

\section{Introduction}

The vegetative tissues of the majority of plants are highly sensitive to water deficit, losing viability upon loss of between 41 and $70 \%$ (depending on the species) of total water content at full turgor (Höfler et al. 1941). While there are many species common to arid and drought-prone regions (extreme examples being succulents) that are able to resist water deficit in the face of drought, these species are 
commonly slow growing and few are suitable for consumption by humans or domesticated animals. Cereals, which make up the bulk of current food supplies, being annuals, inherently have poorly developed abilities to resist vegetative water loss and drought-induced crop failure is an increasingly common phenomenon. With climate change models predicting increased desertification in Australia, much of Africa, North and South America and central Europe over the upcoming years (Dai 2013), it is becoming imperative that alternative strategies be developed for crop production under extreme environmental conditions. To date, attempts at producing crops with shortened growing and fruiting/seeding periods, and improved resistance to water deficit stress, have met with only partial success. It is our premise that production of crops with improved water deficit tolerance will be of value for improved food security in the future.

To this end, there are some 135 angiosperm species, commonly referred to as resurrection plants, that have been reported to survive the loss of up to $95 \%$ of total cellular water content, for prolonged periods of time, and which recover full metabolic activity in existing tissues within 24-72 h of rehydration (reviewed inter alia in Gaff 1977; Alpert and Oliver 2002; Farrant et al. 2007; Moore et al. 2009; Dinakar and Bartels 2013; Gaff and Oliver 2013). Xerophyta viscosa (Baker) (Fig. 1) is a monocotyledonous resurrection plant that we have used as a model to understand mechanisms associated with vegetative tolerance of extreme water loss (desiccation) with the aim of ultimately utilizing some of these properties in the biotechnological production of more drought-tolerant cereal crops. We have undertaken a top-down, bottom-up systems biology approach to identify key protectants and their regulation

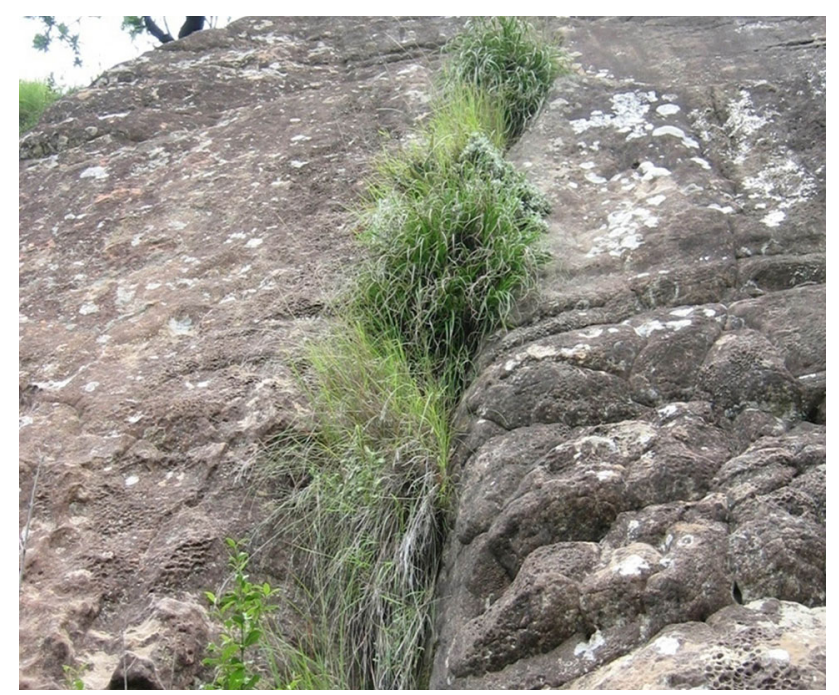

Fig. 1 Xerophyta viscosa growing chasmophytically in the Cathedral Peak Area of the Drakensburg Mountains, KwaZulu Natal, South Africa during dehydration and recovery from the desiccated state, and are attempting to utilize some of these for the development of drought-tolerant strains of Zea mays (maize) - a staple crop in Africa. We present here some of the key findings associated with desiccation tolerance in this species and report briefly on application of these findings in our attempted development of transgenic maize with improved drought tolerance.

\section{Overview of taxonomy, morphology and distribution}

The genus, Xerophyta Juss., is a member of the family Velloziaceae and occurs in Africa, Madagascar and the Arabian Peninsula. It is composed of 45 species, at least ten of which are desiccation-tolerant (Coetzee and Schijff 1973; Coetzee 1974; Behnke et al. 2000, 2013; Behnke 2002; Mello-Silva et al. 2011; Gaff and Oliver 2013). Xerophyta viscosa Baker occurs in South Africa, Lesotho and Swaziland (Fig. 2) in summer-rainfall Afroalpine, subalpine and coastal grasslands (Mucina and Rutherford 2006), where it inhabits rocky terrain or inselbergs in exposed grasslands (Porembski and Barthlott 2000; Behnke et al. 2013) and is typically found hanging off cliff edges (Fig. 1). Several species of Xerophyta, including $X$. viscosa, occur within the species-rich Drakensberg Alpine Centre (DAC), a composite of highaltitude alpine enclaves within the greater Drakensberg range of South Africa renowned for its high plant diversity and endemism (Fig. 2; Carbutt and Edwards 2006). Though mean annual precipitation (MAP) in these regions is moderate (often exceeding $800 \mathrm{~mm}$ : Mucina and Rutherford 2006), the harsh chasmophytic habitat of $X$. viscosa leads to frequent periods of severe water deficit, even during the wet season.

$X$. viscosa is morphologically distinguished from other desiccation-tolerant Xerophyta spp by the formation of chlorophyll-free aquiferous cells between the vascular bundles, the absence of crystals from leaves and the presence of adaxial patellar leaf glands (Fig. 3; Behnke et al. 2013). These glands secrete viscous metabolites including velloziolone, manoyloxide, various diterpenes, phenolic compounds and fatty acids (Naidoo et al. 2009) that play a role in regulating rate of water loss and possibly acting as 'sunscreens' to minimize light activation of chlorophyll during the initial stages of drying (Sherwin and Farrant 1998). This process is known to lead to the formation of extensive reactive oxygen species (ROS) which, if not controlled, cause severe subcellular damage and loss of viability (Smirnoff 2008). The presence of elongated, schlerophyllous leaves permit only minimal folding to reduce the surface area exposed to UV radiation upon 
Fig. 2 Distribution map of Xerophyta viscosa (Baker) in Southern Africa. Mean annual precipitation data for these areas are given. Collection sites are indicated by dashed squares

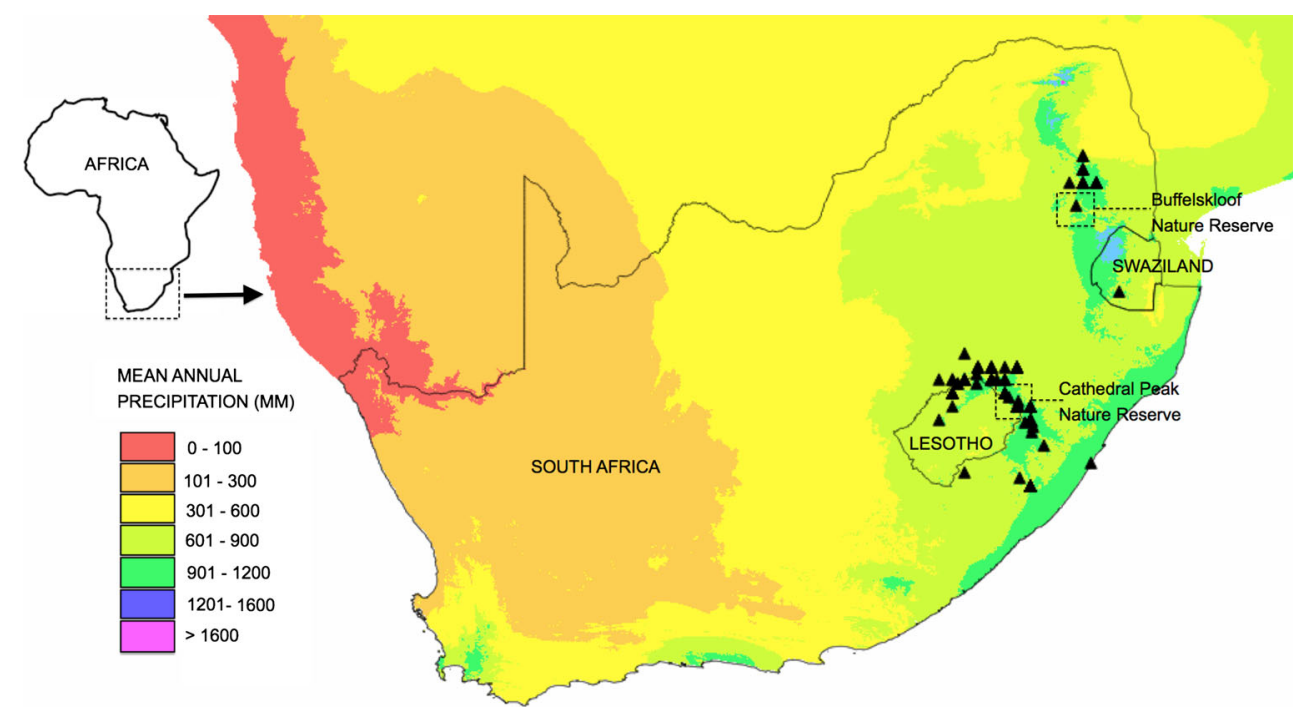

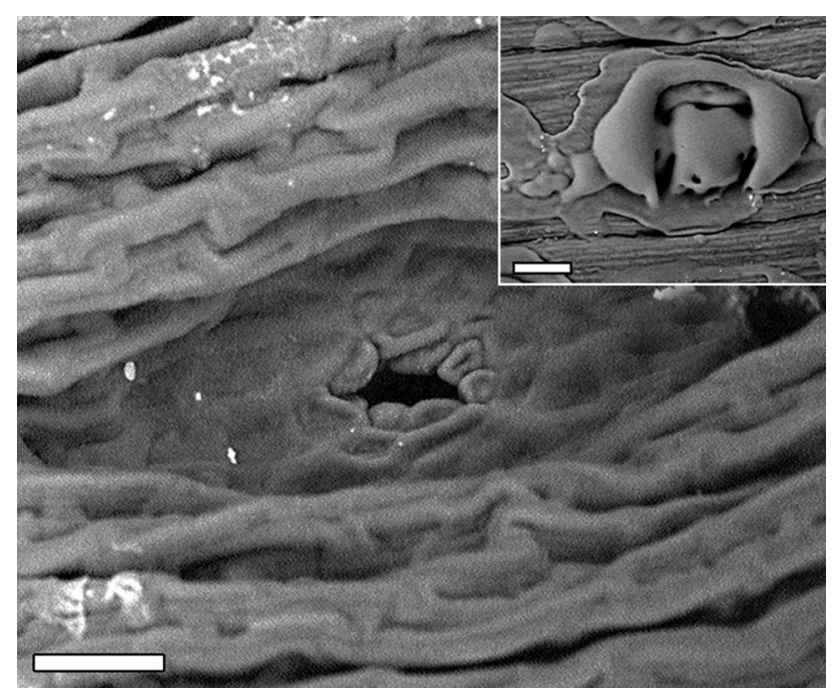

Fig. 3 Scanning electron microscope image of the adaxial surface of a hydrated leaf of $X$. viscosa showing a patellar leaf gland. The inset shows a gland covered by the sticky exudate that it produces. Scale bars represent $20 \mu \mathrm{m}$

dehydration, and thus cellular damage is avoided through its poikilochlorophyllous strategy as the photosynthetic apparatus (chloroplasts and chlorophyll) is dismantled upon dehydration (Sherwin and Farrant 1998; Bhatt et al. 2009). In addition, the exposed abaxial surfaces show an accumulation of purple anthocyanin pigment during dehydration which is also thought to act as a 'sunscreen', reflecting photosynthetically active radiation during periods prior to complete breakdown of chlorophyll or during resynthesis on rehydration. This resynthesis and the repair of damaged tissues and the resultant energy costs result in longer recovery time as compared to species which retain their photosynthetic apparatus (Sherwin and Farrant 1998).

\section{Plant collection, maintenance and methodology}

Our research has been conducted on plants collected from Buffelskloof Nature Reserve near Lydenberg (Mpumalanga Province, South Africa) and Cathedral Peak Nature Reserve in the Drakensberg mountains (Kwazulu-Natal, South Africa) (indicated in Fig. 2). Plants were maintained under glasshouse conditions at the University of Cape Town (South Africa) until required for dehydration and recovery experiments (Sherwin and Farrant 1996). For such experiments, plants were placed in a controlled environment chamber $\left(16 \mathrm{~h}\right.$ light, $350 \mu \mathrm{mol} \mathrm{m}{ }^{-2} \mathrm{~s}^{-1}, 25{ }^{\circ} \mathrm{C}$; $8 \mathrm{~h}$ dark, $20{ }^{\circ} \mathrm{C} ; 50 \%$ relative humidity) and were allowed to acclimate for a minimum of 2 weeks prior to experimentation. Plant dehydration was achieved by withholding water until tissue water content reached an air dry state $(\leq 5 \%$ water content relative to the fully hydrated state). They were maintained in the dry state for longer than 1 week, following which rehydration was achieved by soil watering. Plants were well watered on the first day and the soil was kept damp for the remainder of the experiments. Tissues were sampled regularly during the drying and rehydration treatments for physiological and molecular experiments referred to below. No significant differences in responses to desiccation were noted among plants collected from these different sites.

Dehydration of root and leaf tissues to the air dry state under these conditions takes ca 9 and 15 days, respectively, with leaf rehydration to full turgor taking 3 days (Fig. 4; Sherwin and Farrant 1996; Mundree and Farrant 2000; Kamies et al. 2010). Roots from mature plants of this species are particularly recalcitrant to methodologies typically used for biochemical and molecular studies (Kamies et al. 2010; Kamies 2011) and unless otherwise 
Fig. 4 Changes in leaf RWC with images of Xerophyta viscosa plants during dehydration (a-f) and rehydration $(\mathbf{e}-\mathbf{g})$ under a $16 \mathrm{~h}$ light, $350 \mu \mathrm{mol} \mathrm{m}{ }^{-2} \mathrm{~s}^{-1}, 25^{\circ} \mathrm{C}$ and $8 \mathrm{~h}$ dark, $20^{\circ} \mathrm{C}$, regime. a Fully hydrated plant (100\% RWC). b $70 \%$ RWC. c $35 \%$ RWC. d $7 \%$ RWC. e $45 \%$ RWC. f $65 \%$ RWC. g $80 \%$ RWC. Absolute water contents were determined gravimetrically as described in van der Willigen et al. (2001) with RWC being calculated from this and the mean water content of tissues at full turgor. All the images are of the same plant except image (b) which is a plant of similar size and age under the same stress treatment in the same growth room
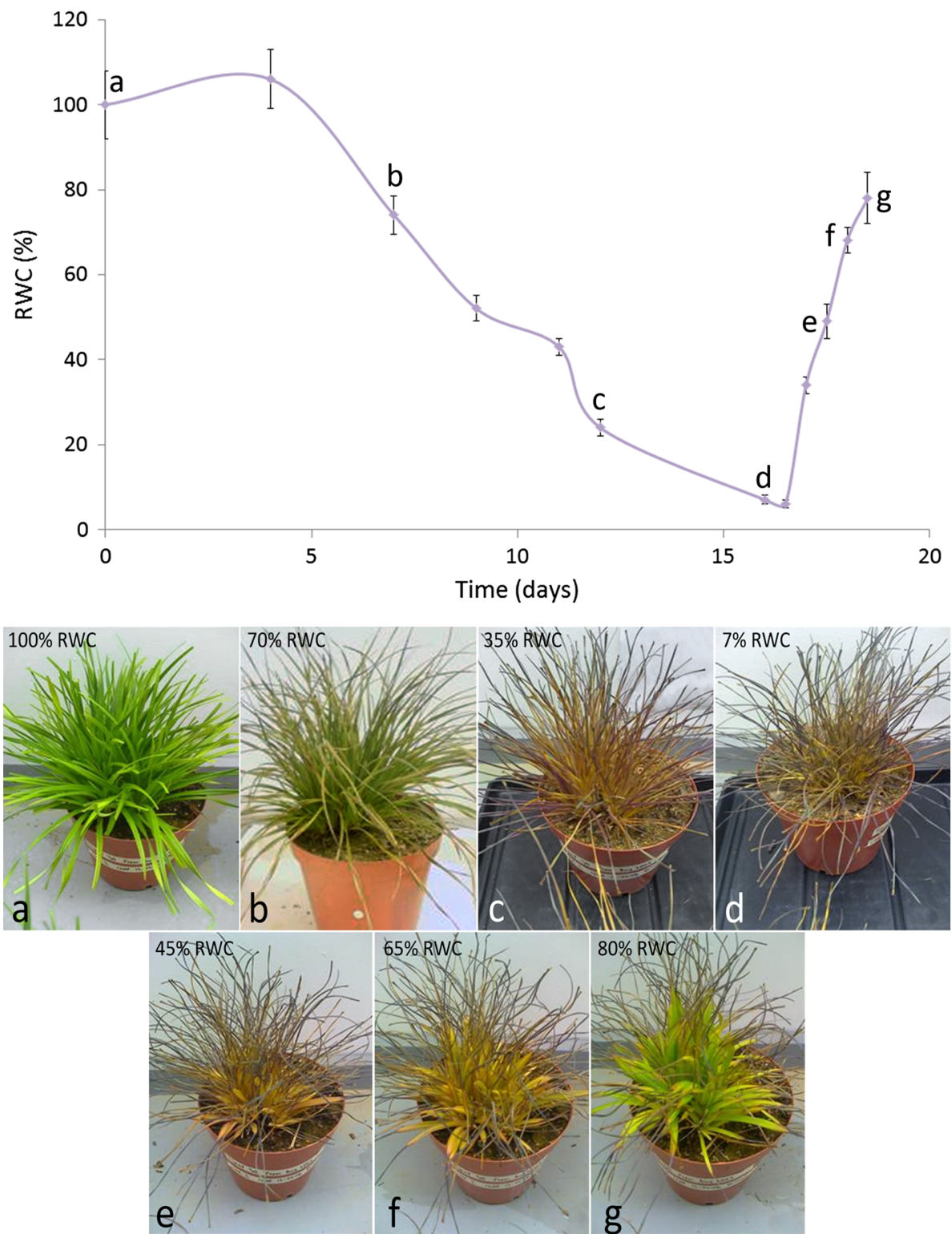

stated, the data presented below are for leaf tissues only. The changes in leaf water content on drying follow a reverse sigmoidal pattern typical of most resurrection plants we have studied to date (Fig. 4; Farrant et al. 2007), and we have tentatively identified 3 stages to this process. (1) An early response to drying (ERD) in which relative water content (RWC) declines from full turgor to ca $55 \%$ during which leaf colour changes from green to yellow (as seen in Fig. 4a, b) indicative of photosynthetic shutdown (discussed below). (2) A late response to drying (LRD) occurring between 55 and $10 \%$ RWC during which leaves fold adaxially, exposed surfaces becoming anthrocyanin rich (Fig. 4c). (3) Below $10 \%$ RWC, respiration ceases and tissues reach an air dry state (ADS) of $\leq 5 \%$ RWC (Mundree and Farrant 2000). We have noted in this and other species, that there are subtle quantitative and qualitative changes in transcripts, protein and lipids during maintenance in the ADS (data unpublished), this possibly being equivalent to processes typical of dry after-ripening or dormancy in seeds, in which this metabolism is purported in part to occur in hydrated cellular pockets and is required for germination related processes (Leubner-Metzger 2005: Oracz et al. 2007) and/or due oxidative changes associated with Amadori and Maillard reactions that occur in the dry state (Priestly 1986; Sun and Leopold 1995). To date, there is little known about the cellular and molecular mechanisms involved in these processes and this is an area requiring further investigation.

Stresses associated with water loss (Vertucci and Farrant 1995; Walters et al. 2002; Farrant et al. 2012) during ERD are plasmolysis and cytorrhysis as a consequence of turgor loss, and oxidative as a consequence of ongoing 
photosynthesis in a water-limited subcellular environment. During the LRD, plant tissues are subject to further oxidative stresses as metabolism becomes increasingly unregulated and metabolic crowding and membrane appression takes place. In the ADS, Maillard and Amadori reactions, autoxidation, protein and membrane destabilization occurs. $X$. viscosa is able to prevent damage associated with such stresses and redirect metabolism for successful recovery upon rehydration as discussed below.

Table 1 shows the expression patterns of transcripts and proteins that change significantly during dehydration of $X$. viscosa and putative integrative changes are modelled in Fig. 5. Transcriptome analysis was achieved by using complementation by functional sufficiency in Escherichia coli (Mundree and Farrant 2000) and differential screening of dehydration expression libraries (Ndima et al. 2001; Iyer et al. 2008). Proteome analyses were conducted on leaves and isolated nuclei using 2D PAGE and ITRAQ analyses, respectively (Ingle et al. 2007; Abdalla et al. 2010; Abdalla and Rafudeen 2012). There is no genome sequence available for resurrection plants and thus full annotation of transcripts and proteins up- or down-regulated has not been possible. This, together with the challenges of capturing subtle ongoing changes during a prolonged period of dehydration and recovery therefrom, and technological limitations associated with detection of minor but possibly important changes, preclude definitive interpretation of what is actually required for tolerance of extreme water loss. What we describe below can be considered a contribution towards a broader understanding of the phenomenon of vegetative desiccation tolerance.

\section{Early stage dehydration}

\section{Gene expression (signalling and translation)}

The initiation of the response to water deficit begins with signal transduction. However, changes in gene expression via these signalling events require and depend upon prior post-translational modifications to the nucleosome histone structure and DNA methylation (Chinnusamy and Zhu 2009; Sahu et al. 2013). The chromatin is remodelled under water deficit stress conditions by various proteins such as histone modification enzymes and linker histone $\mathrm{H} 1$ among others (Kim et al. 2010). The latter specifically allows protein contacts for the next level of chromatin structure and are easily modified post-translationally. A few drought-induced linker histone H1 variants have been characterized to date and seem not to be essential for growth and development (Wei and O'Connell 1996; Ascenzi and Gantt 1997). It has been suggested that these histone $\mathrm{H} 1$ variants are required to change the transcriptional activity of the cell undergoing water loss by altering the chromatin structure to either allow and/or suppress the binding of transcription factors to the DNA (Scippa et al. 2000). Transcript levels of a X. viscosa linker histone H1 variant, XvDIH1v, homologous to the droughtinduced $\mathrm{H} 1$ variants, increases when water content declines to $55 \%$ RWC, after which it appears to be down-regulated (Holiday 2007). Overexpression of this protein in tobacco increases tolerance to various abiotic stresses (Wang et al. 2014).

Our studies also show an early upregulation (at $75 \%$ RWC) of a protein phosphatase [homologous to Type 2C from A. thaliana (CAB79642)] at both the protein and transcript level, the protein declining upon further dehydration (Ingle et al. 2007; Umezawa et al. 2009). Phosphatases are thought to act as negative regulators of protein kinase and ABA signalling pathways and such a negative feedback loop allows the plant to reset the ABA signalling pathway in order to continually monitor the presence or absence of ABA (Gosti et al. 1999). Interestingly, an ABAresponsive desiccation-related protein is synthesized de novo in the LRD, which has been proposed to be related to regulation of signalling (Ingle et al. 2007).

Transcripts of a calcium-binding protein containing three EF-hands with high similarity to plant calmodulins (Xv-CAM) increased significantly upon initial drying, with the protein itself becoming evident (through use of western blot analysis) below water contents of $55 \%$ (Conrad 2005; Abdalla and Rafudeen 2012). The protein remains highly expressed until the early stages of rehydration $(40 \%$ RWC) after which little protein was detected (Conrad 2005). $\mathrm{Ca}^{2+}$-mediated signalling in response to abiotic stresses is a well reported phenomenon and overexpression of rice calmodulin (Os MSR2) enables enhanced drought tolerance in Arabidopsis thaliana (Xu et al. 2011). While the molecular and physiological functions of such proteins are not completely understood, it is widely thought that they regulate calcium levels through a tight networks of sensory proteins, membrane pumps and ion channels, which inter alia allow for the spatial and temporal management of the resultant calcium signal with consequent down-stream ABA signalling and protectant effects (McAinsh and Hetherington 1998; Pittman and Hirschi 2003; Hirschi 2004).

In A. thaliana a number of proteins are induced as an early response to drying and which have thus been termed ERD proteins (Kiyosue et al. 1994) Transcripts and proteins of an ERD15-like protein are strongly induced at $75 \%$ RWC, with expression being maintained until ca $30 \%$ RWC, after which both protein and transcripts decline, being absent during the early stages of rehydration (Lee 2005). XvERD15 is a small, acidic protein with 46,41 and $38 \%$ overall amino acid identity to ERD15 


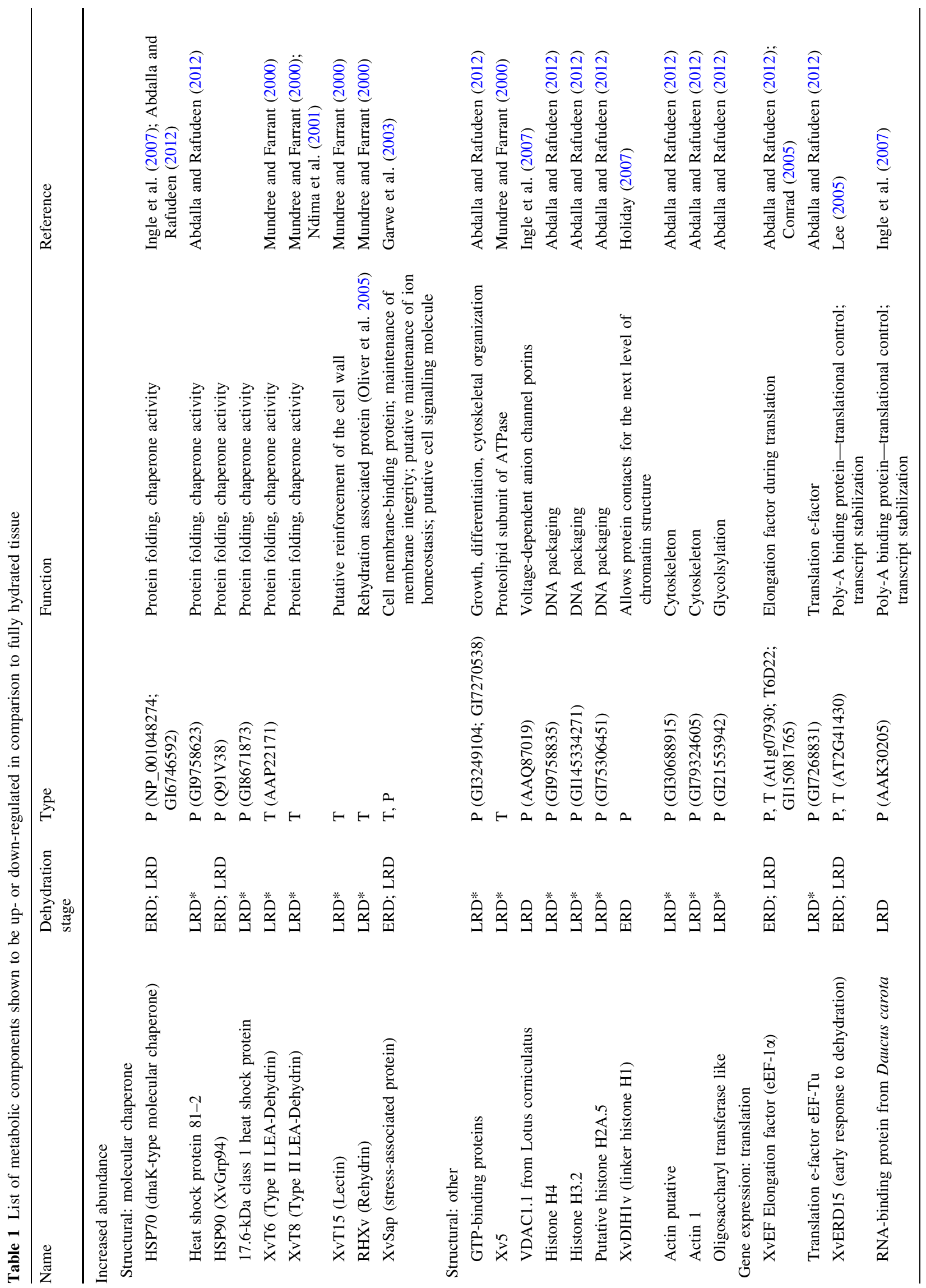




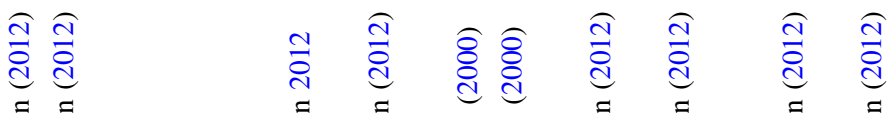

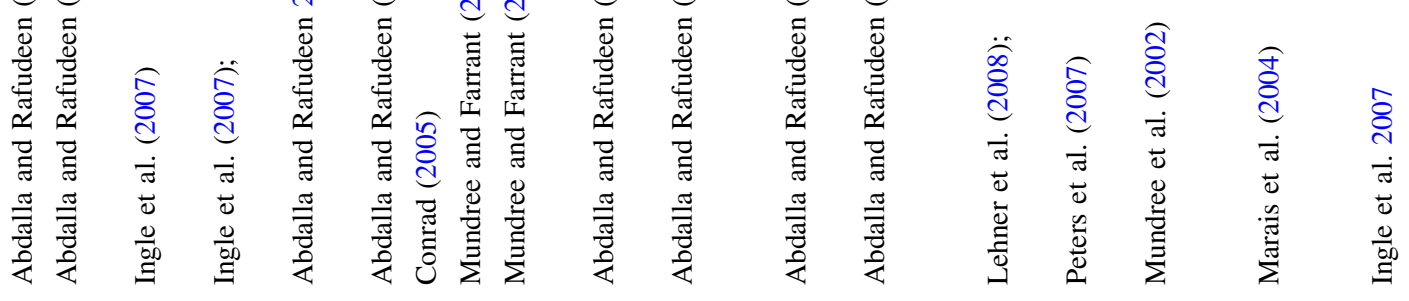

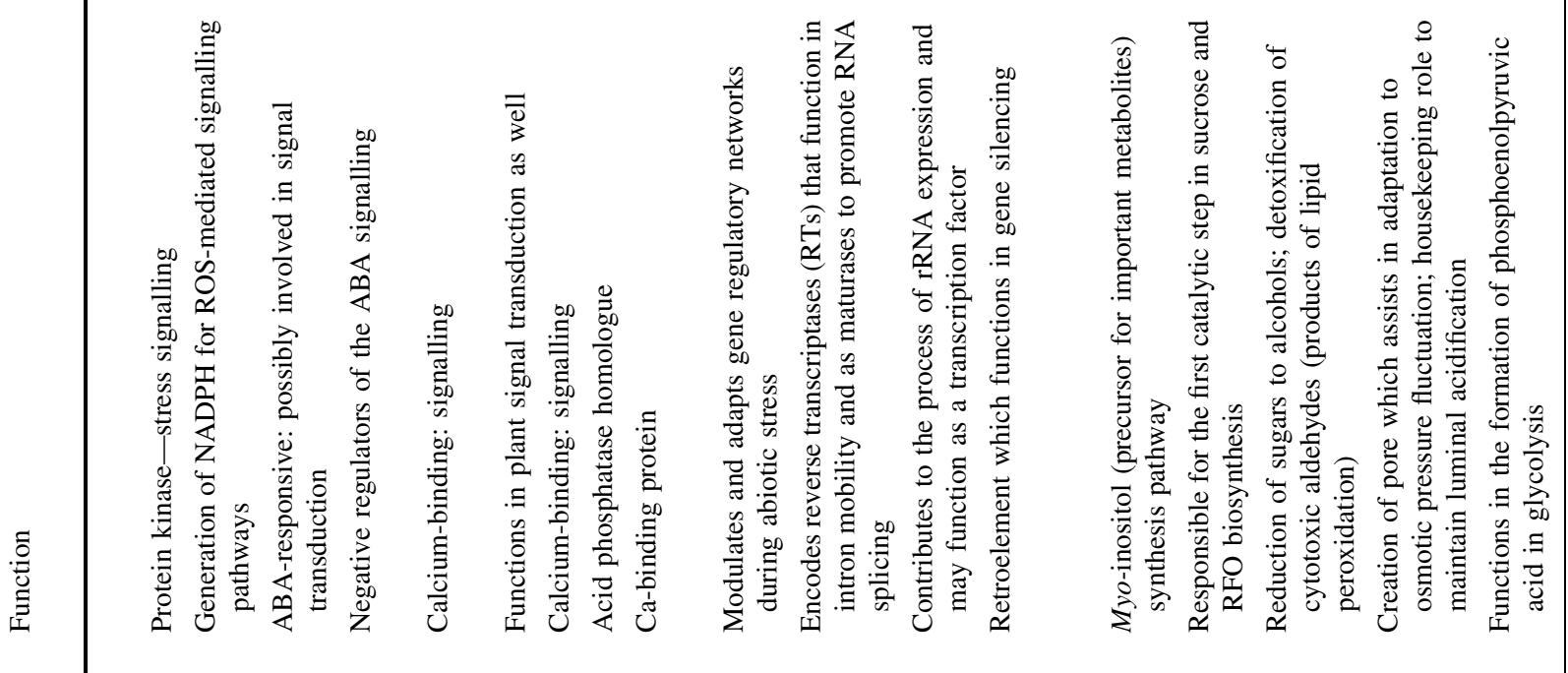

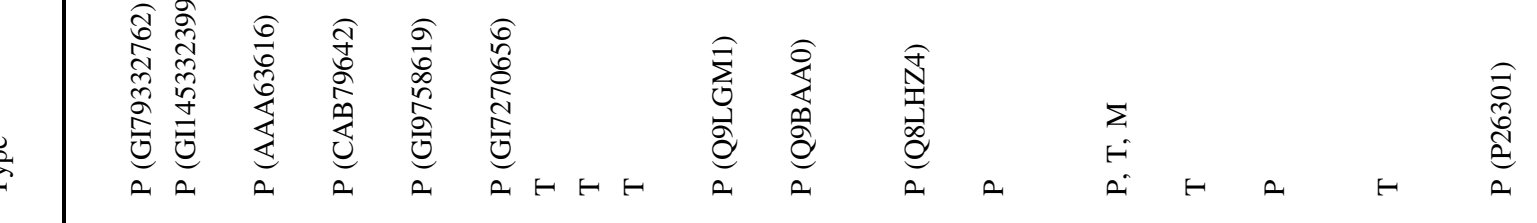

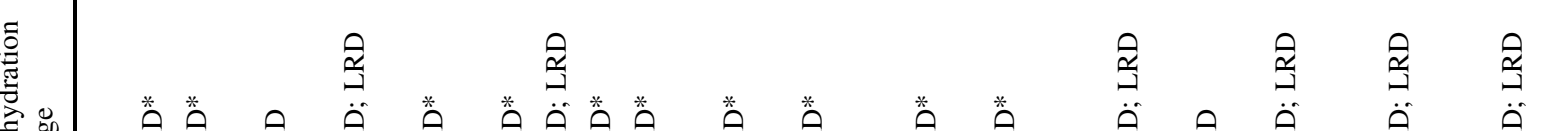

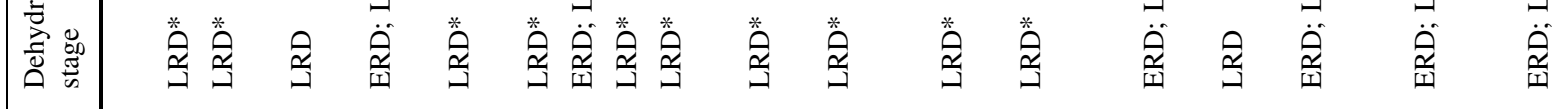

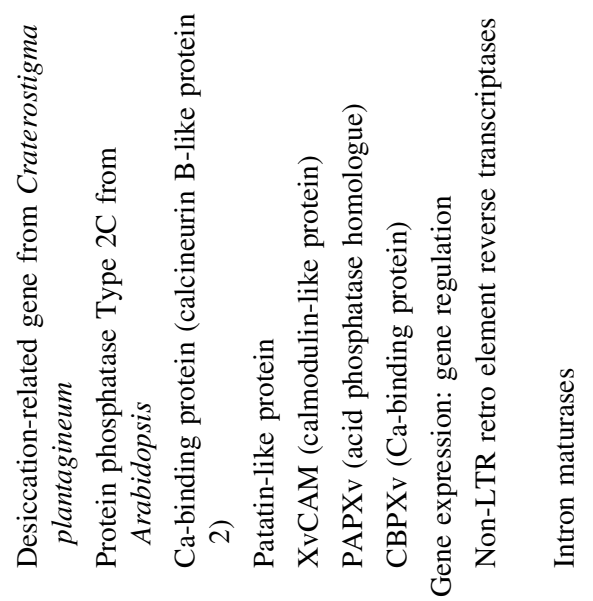

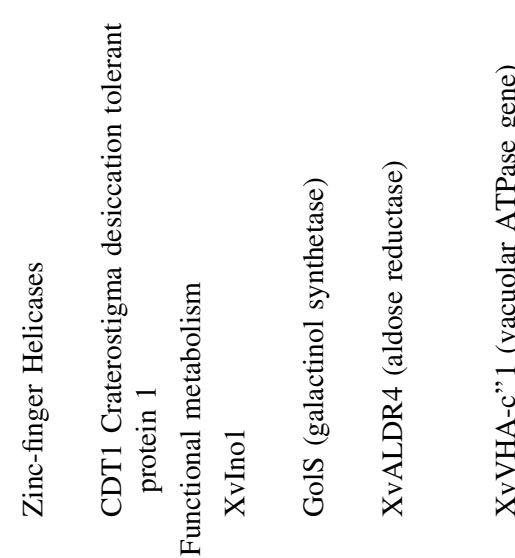

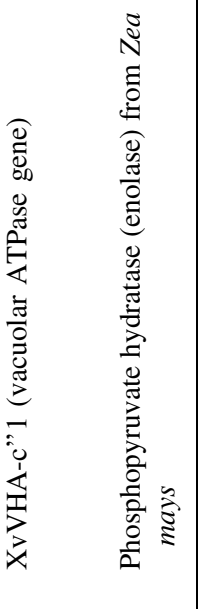




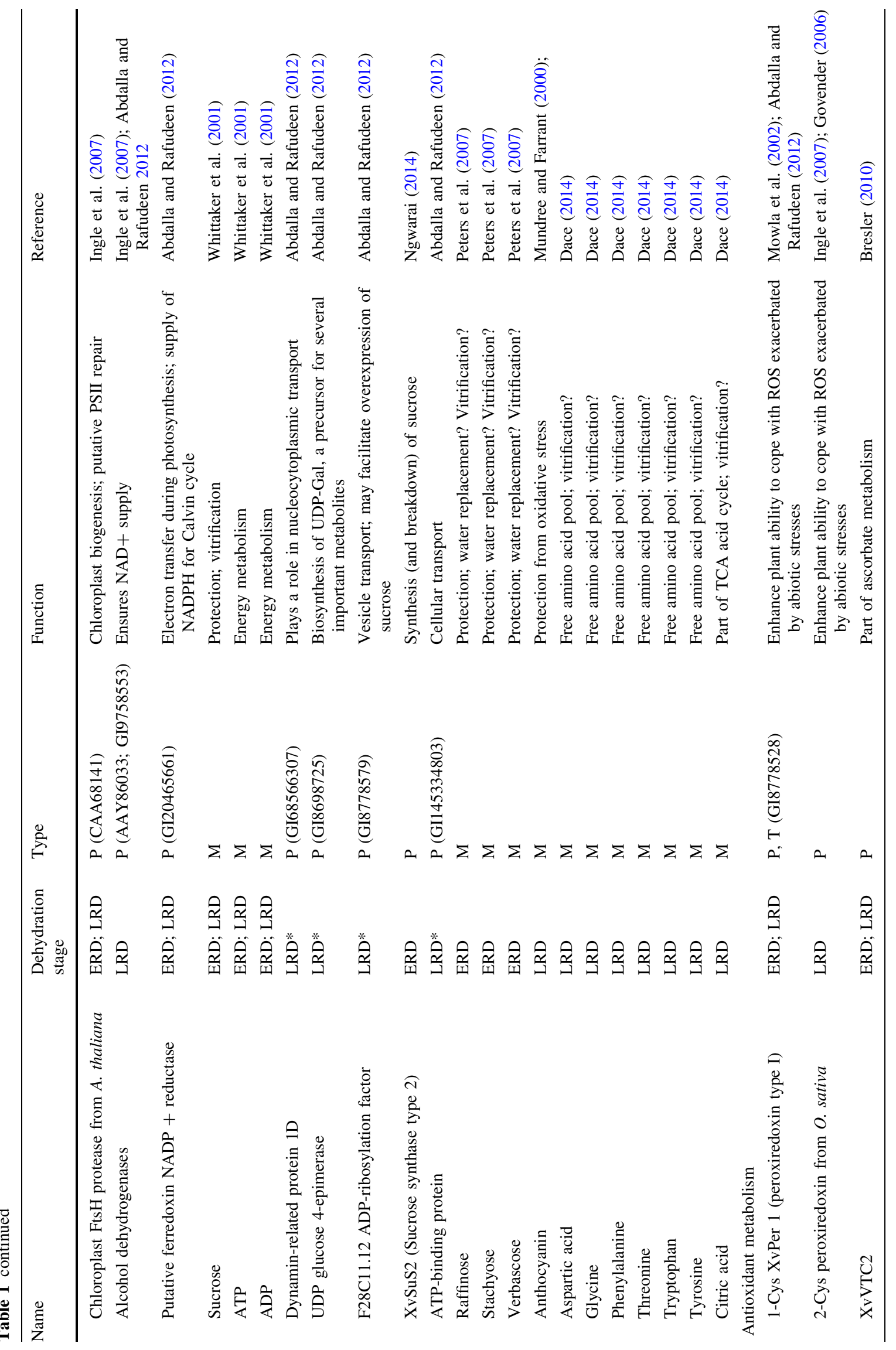




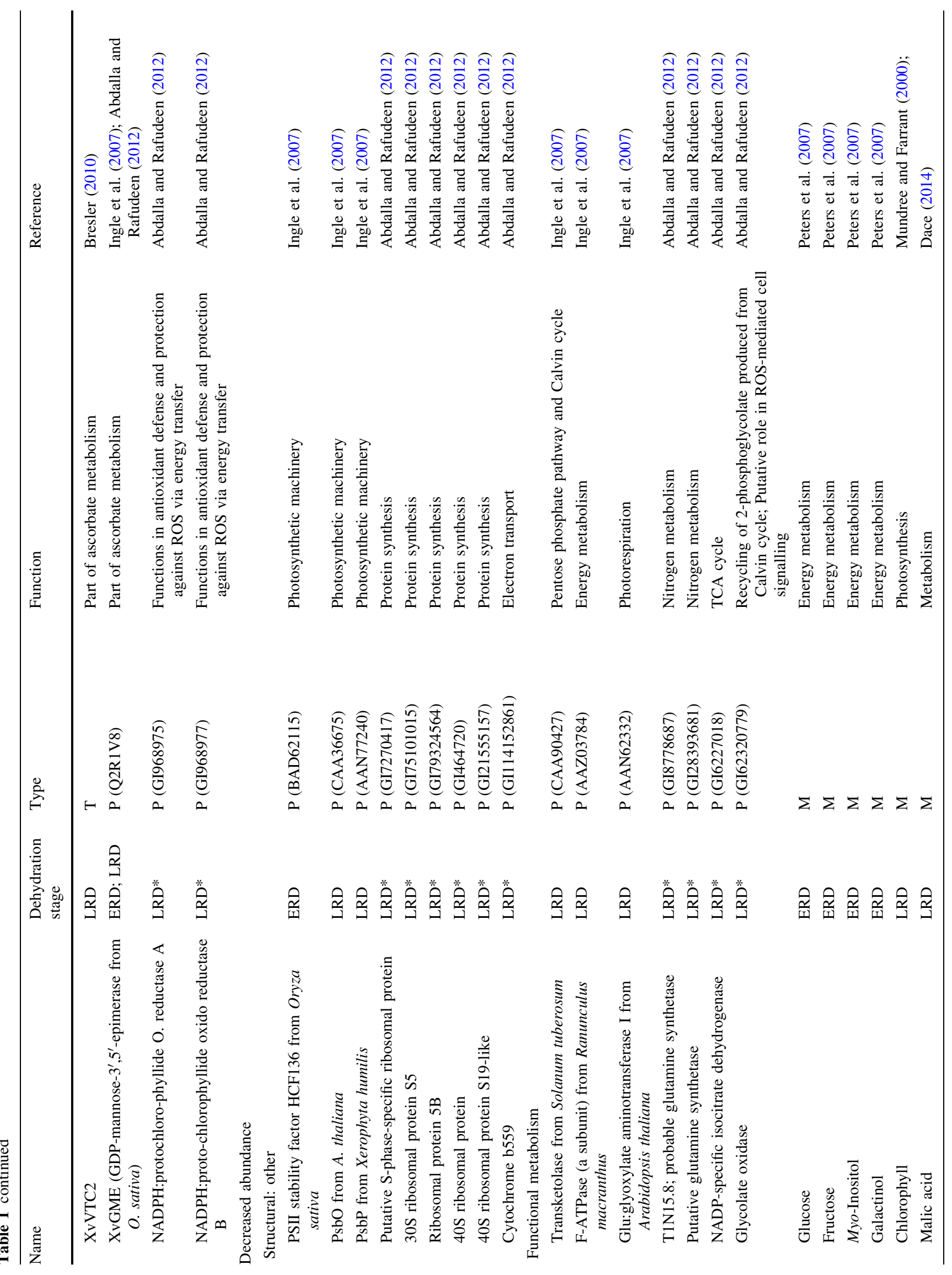


homologues in rice, tomato and Arabidopsis, respectively. Kariola et al. (2006) showed using A. thaliana lines in which AtERD15 was either silenced or over-expressed, respectively, and by measuring AtERD15 transcript content in abi mutants, that ERD15 is a negative regulator of the ABA response. It was proposed that the modulation of the amounts of ERD15 synthesized alters the responsiveness to the ABA signal, possibly downstream of ABI 1 and ABI 2, via regulating stomatal aperture (Kariola et al. 2006; Aalto et al. 2012). Those authors further proposed that ERD15 acts to delay the stress signal (abiotic or biotic, respectively) until sufficient stimuli are received before the plant commits to the large-scale adaptation to the specific stress. It is speculated that XvERD15 provides an ABA regulated threshold, or 'tipping point', for commitment to mechanisms that ensure tolerance of extreme water loss.

\section{Responses to mechanical stress}

Reduction in cell volume as a consequence of water deficit results in mechanical stresses of plasmolysis as tension is placed on regions of the plasma membrane attached to cell walls and ultimately cytorrhysis, during which walls collapse and cell death ensues (Iljin 1957). In X. viscosa leaf tissues, these stresses appear to be ameliorated largely by the sequential subdivision of the large central vacuole into smaller vacuoles in which water is replaced with compatible solutes (Mundree and Farrant 2000), the result of which becomes clearly evident at water contents below $55 \%$ RWC (insets, Fig. 5). In parallel with these changes, there was is upregulation of both transcripts and proteins of a vacuolar adenosine triphosphatase (V-ATPase) proteolipid subunit $\mathrm{c}^{\prime \prime}$ homologue (XvVHA-c"1) which is proposed to be involved, inter alia, in energy required for vacuolar transport (Marais et al. 2004).

Unlike in many other resurrection plants such as Craterostigma spp. (Vicré et al. 1999, 2004) and Boea hygroscopica (Wang et al. 2009), there is little evidence of wall folding during drying. Wall composition analysis, involving assessment of monosaccharide composition, comprehensive microarray polymer profiling and FT-IR spectroscopy in combination with multivariate data analysis, has confirmed a lack of quantitative and architectural changes during dehydration (Moore et al. 2013). However, walls of this species contain high amounts of arabinosylated xylans and arabinogalactan proteins (AGPs). Elevated arabinan polymers (as arabino pectins typified in dicotyledons or arabinosylated xylans in monocots) in combination with AGPs are a common feature in all resurrection plants ( 7 species) subject to such analysis (Moore et al. 2013). These authors have proposed that, since arabinose polymers are highly mobile, they allow wall flexibility (Foster and Ablett 1996; Renard and Jarvis 
Fig. 5 Diagram of changes occurring in cells in early stage dehydration (a) and late stage dehydration (a) showing the probable locations of these changes. Green symbols indicate upregulation and red symbols show down-regulation. Proteins are represented by circles, transcripts by squares and metabolites by triangles. Insets show transmission electron micrographs at approximately $65 \%$ (a) and $37 \%$ (b) RWC. Scale bar represents $2 \mu \mathrm{m}$ a
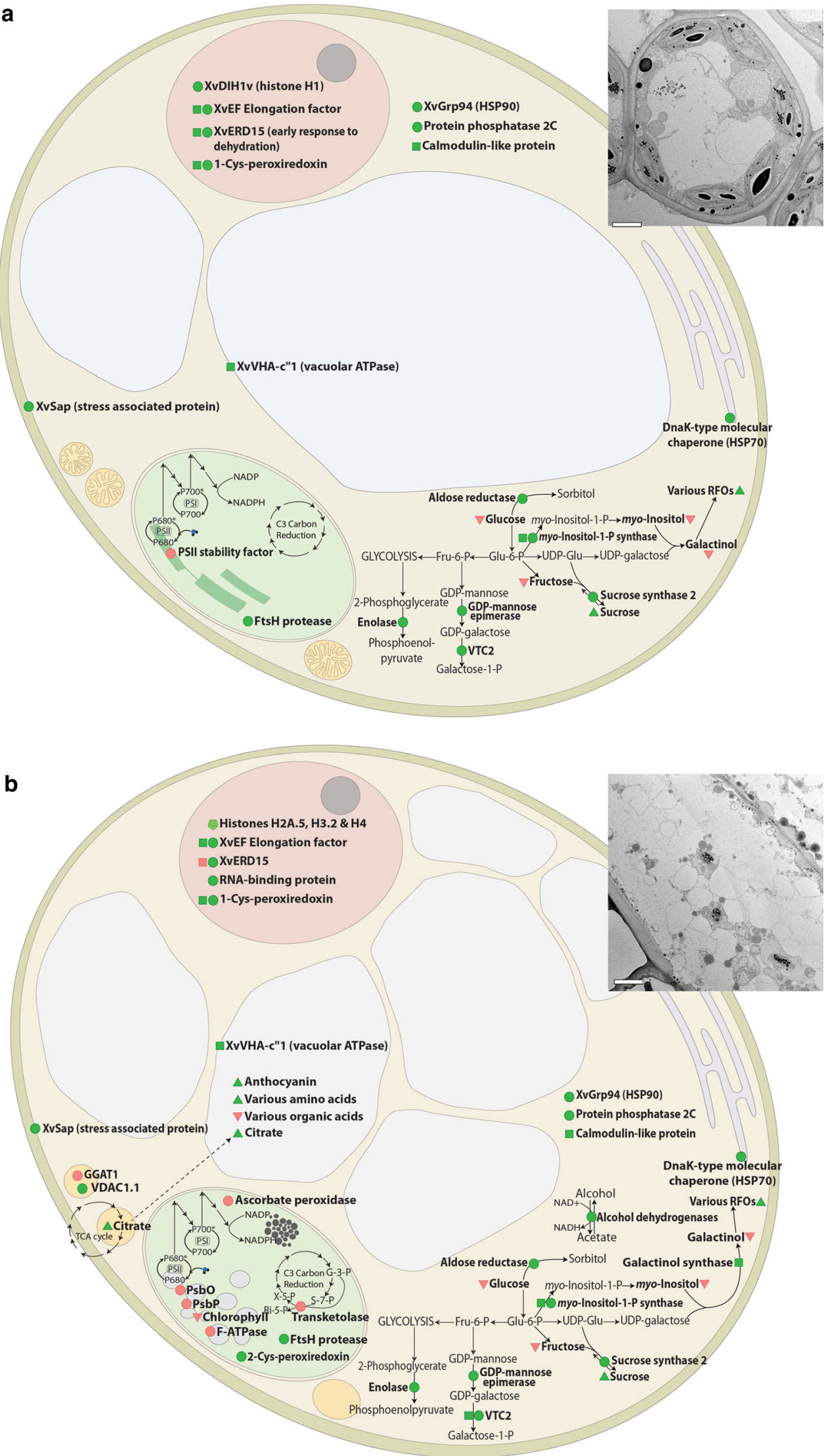
1999) and have a high water-absorbing capacity (Goldberg et al. 1989; Belton 1997) which is important for rehydration. Such a constitutively high arabinan content is indicative of a constant preparedness for dehydrationrehydration.

\section{Oxidative stress and antioxidants}

Water deficit results in oxidative stresses as a consequence of perturbation of metabolism in general, but metabolism involving electron transport is particularly susceptible to ROS formation (Foyer et al. 1994; Halliwell and Gutteridge 1999; Apel and Hirt 2004; Foyer 2010). Electron leakage during photosynthetic electron transport and the formation of singlet oxygen are significantly increased when cells of photosynthetic tissues suffer water loss and this has frequently been cited as a primary cause of damage and resultant plant death in most species (Seel et al. 1992; Smirnoff 1993; Kranner and Birtić 2005). X. viscosa is a poikilochlorophyllous resurrection plant (Sherwin and Farrant 1998) in which chlorophyll is degraded and thylakoids dismantled, effectively shutting down photosynthesis by $55 \%$ RWC, while simultaneously reducing photosynthetically produced ROS (Mundree and Farrant 2000). Chlorophyll degradation is a regulated process (and not simply a consequence of photooxidative breakdown), occurring via the pheophorbide $\alpha$ oxygenase (PAO) phyllobilin pathway, the phyllobilin catabolites formed being accumulated in the vacuole and subsequently degraded during early rehydration (Christ et al. 2013). Dismantling of thylakoid membranes is typified by an early onset of decreased abundance of LHCb1, chlorophyll-binding light harvesting protein of PSII, and the thylakoid luminal protein, HCF136 required for PSII stability. These data support the contention that controlled shutdown of particularly PSII complexes during desiccation plays a considerable role in minimizing dehydration induced photosynthetic ROS (Dinakar et al. 2012; Farrant et al. 2012; Christ et al. 2013). Interestingly, this is true too of the homoiochlorophyllous resurrection plant Craterostigma pumulim, in which photosynthetic shutdown has been shown to be achieved primarily by structural rearrangements of PSII complexes into a photochemically quenched state (Charuvi et al. 2015). Reappearance of chlorophyll and thylakoid proteins is initiated after $24 \mathrm{~h}$ of rehydration (50\% RWC) and the photosynthetic apparatus is fully reconstituted after 3 days, this corresponding to achievement of full turgor (Sherwin and Farrant 1996; Christ et al. 2013; also shown in Fig. 3). In the related resurrection plant, Xerophyta humilis, resynthesis of chlorophyll and initial reconstitution of thylakoid membranes is independent of de novo transcription, suggesting that stable storage of transcripts is required for re-activation of photosynthesis during recovery (Dace et al. 1998). This is likely to occur in $X$. viscosa as well, as there is increased presence of RNA binding proteins purported to stabilize transcripts during the late stages of drying (Ingle et al. 2007; Abdalla and Rafudeen 2012).

During the ERD in $X$. viscosa, there is an increase in ascorbate and GDP mannose- $3^{\prime}, 5^{\prime}$-epimerase (an enzyme involved in ascorbate synthesis) as well as the activities of glutathione reductase (GR), chloroplastic superoxide dismutase ( $\mathrm{CuZn} \mathrm{SOD),} \mathrm{catalase} \mathrm{and} \mathrm{ascorbate} \mathrm{peroxidase}$ (Sherwin and Farrant 1998; Mundree and Farrant 2000; Farrant et al. 2007; Ingle et al. 2007; Kamies et al. 2010). Early induction of 'housekeeping' antioxidant potential occurs in desiccation-sensitive species in response to water deficit (reviewed in Farrant et al. 2007) and thus X. viscosa behaves no differently. However, it is the maintenance of this and other antioxidant potential during the later stages of drying (reviewed below) that help differentiate this species from drought-sensitive plants.

While numerous metabolic shifts are likely to occur during ERD, the major differences observed in our studies are portrayed in Fig. 5a. In particular, there is an increase in metabolism associated with the ascorbate pathway and redirection of metabolism to the increased formation of sucrose, raffinose family oligosaccharides (RFOs) and sorbitol. Accompanying these there is evidence of increased glycolysis resulting inter alia in increased carbon allocation to the phosphophenol pyruvate pathway.

\section{Late stage dehydration}

Dehydration below $55 \%$ (Fig. 4c-e), a relative water content beyond which most plant species lose viability, is accompanied by numerous shifts in the transcriptome, proteome and metabolome (Table 1; Fig. 5b).

\section{Gene expression (signalling and translation)}

In a study of the nuclear proteome during drying of $X$. viscosa, Abdalla and Rafudeen (2012) have shown considerable upregulation of proteins involved in signalling processes that they propose are relevant predominantly in the late stages of dehydration, in that such proteins were highly expressed at $35 \%$ RWC and below. Among these are a Ca-binding protein with similarity to calcineurin B-like protein 2, a malate dehydrogenase that is involved in the generation of NADPH for ROS-mediated signalling reactions (Apel and Hirt 2004), patatins and glycoproteins that function in signal transduction. Furthermore, the cell signalling-related protein phosphatase Type $2 \mathrm{C}$, which first appear in the early stages of dehydration, is maintained at high concentrations during LRD. Such changes have been 
implicated in the regulation of ROS-scavenging machinery and mediation of other cell signalling processes required under abiotic stress situations (Davis 2005).

Other genes noted to be upregulated in X. viscosa during late stage dehydration include retroelements (speculated to be instrumental in gene silencing, particularly in response to stress, Nakaminami et al. 2012), XvZPR1 (a zinc-finger helicase and a proposed transcription factor) and expression of an RNA-binding protein homologous to a maturase found in Daucus carota which is ostensibly involved in binding and stabilization of mRNA (Wang et al. 2014). Similar changes occur during the final stages of dehydration in the closely related X. humilis (Collett et al. 2003, 2004), giving support to the contention that they are highly relevant to overall stabilization of the subcellular milieu at low water contents and maintenance of quiescence while in the dry state. In addition, there is an upregulation of an oligosaccharyl transferase-like protein that likely functions in post-translational modification by $N$-glycosylation (Abdalla and Rafudeen 2012) and a membrane-binding protein XvSAP1 (a stress-associated protein with homologies to a WCOR413, a cold-responsive protein from wheat, rice and A. thaliana and a potassium transporter) that might play a role in signal transduction in response to abiotic stresses (Garwe 2003; Garwe et al. 2003; Iyer et al. 2008).

\section{Oxidative stress and antioxidants}

During the LRD there is further decline in proteins associated with photosynthesis (particularly psbP and components of the luminal oxygen evolving complex (OEC) of PSII (Ingle et al. 2008) further minimizing potential ROS generation from photosynthetic activity. However, drying below $55 \%$ RWC results in ROS formation from ongoing respiration and perturbation of other metabolisms as a consequence of the considerably reduced aqueous environment within tissues (Mundree and Farrant 2000; Walters et al. 2002). In general, protein housekeeping antioxidants do not show a further increase in activity during LRD, and some, like catalase and ascorbate peroxidase decline in activity at this stage. Interestingly, however, enzyme antioxidants that are present remain undenatured during drying and retain the ability to detoxify ROS during the LRD and early rehydration, as evidenced by in vitro analysis of extracted proteins (Sherwin and Farrant 1996; Mundree and Farrant 2000; Farrant et al. 2007). Transcripts of GDP-L-galactose phosphorylase (Xv VTC2; the first committed enzyme in the synthesis of ascorbate) increase by 1000 -fold during LRD, but protein expression and ascorbate concentrations remain unelevated until the early stages of rehydration after which considerable increases in both occur (Bresler 2010). These data collectively suggest that maintenance (however this is achieved) of housekeeping antioxidant potential during drying and early rehydration is important to survival of extreme water loss. But it is clear that other antioxidant systems, not usually upregulated in desiccation-sensitive material, are also required for survival of desiccation. For example, there is significant upregulation of a nucleus-associated antioxidant 1-Cys peroxiredoxin (XvPer1, Mowla et al. 2002), to date reported to be specific to desiccationtolerant seed tissues (Leprince and Buitink 2010). There is also an increase in transcript and protein of a type II peroxiredoxin ( $X v P r x 2)$, a chloroplast-targeted protein that reduces peroxide substrates to the corresponding alcohol and water (Govender 2006; Dietz 2011). Increased polyphenol content during late drying have also been implicated in antioxidant defence as their relative antioxidant potential as determined by FRAP (ferric reducing/antioxidant power) and DPPH (2,2-diphenyl-1-picrylhydrazyl) shows higher activity in $X$. viscosa (and other resurrection plants) than in related desiccation-sensitive species (Farrant et al. 2007, 2012). Given the complexity involved in redox balancing (Foyer and Noctor 2005, 2009) it is probable that these are only a few of the components involved in antioxidant metabolism during LRD, with cytoplasmic vitrification, which progressively occurs during this stage (see below), further contributing to ROS stasis.

\section{Macromolecular stabilization and induction of metabolic quiescence}

During the late stages of drying cellular contents become concentrated, increasing the likelihood of inappropriate molecular interactions and membrane appression. Ultimately the lack of sufficient water to surround macromolecules causes their denaturation and loss of membrane integrity (Vertucci and Farrant 1995; Walters et al. 2002). The ability to withstand such water loss therefore requires unique protective adaptations.

It is thus no surprise that during LRD there is induction of four heat shock proteins (HSP 70, 81-2; 90 and a 17.6$\mathrm{kDa}$ class $1 \mathrm{HSP}$ ) with putative chaperonin activity (Walford et al. 2003; Ingle et al. 2007; Abdalla et al. 2010; Abdalla and Rafudeen 2012). HSPs accumulate during acquisition of desiccation tolerance in seeds (Vierling 1991; Wehmeyer et al. 1996; Buitink et al. 2006) and other resurrection plants (Alamillo et al. 1995; Walford 2008), firmly establishing their role in desiccation tolerance. In addition to the classical protein folding role of chaperonins, they (XvHSP 90 in particular) have been evoked in binding to non-native proteins preventing their aggregation (Walford et al. 2003) and in some instances in signal transduction via interactions with plant growth regulators and certain protein kinases (Picard et al. 1990; Bohen and Yamamoto 1994; Buchner 1999). 
Although precise functions of most Late Embryogenesis abundant (LEA) proteins are still largely unknown, many have been implicated in tolerance of water deficit stress (reviewed in Cuming 1999; Illing et al. 2005; Leprince and Buitink 2010; Tunnacliffe and Wise 2007; Tunnacliffe et al. 2010; Farrant et al. 2012). Unpublished data from our laboratory indicate the presence of 21 LEA-like proteins in the genome of $X$. viscosa, only two of which (XvT6 and XvT8, both Type II or dehydrin-like proteins) have been functionally characterized (Mundree and Farrant 2000; Ndima et al. 2001). Transcripts and proteins are ABA inducible and become evident upon drying below $40 \%$ RWC, expression declining rapidly during rehydration in a pattern typical of desiccation-tolerant plant tissues (Illing et al. 2005; Leprince and Buitink 2010). Dehydrins are induced in response to water deficit in several desiccationtolerant systems (Ingram and Bartels 1996; Close 1997) and are constitutively expressed in the moss Tortula ruralis (Bewley et al. 1993). Because such proteins are mostly unfolded in aqueous solutions, it is experimentally difficult to assign to them a structure and function and thus the predicted roles for LEA proteins have been based largely on RNA sequence information. These include (1) water replacement molecules and/or hydration buffers; (2) ion sequesters; (3) chaperonins and/or heat shields; (4) protein/ membrane anti-aggregants and membrane stabilizers; and (5) promoters of vitrification (Bray 1997; Hoekstra et al. 2001; Wise and Tunnacliffe 2004; Bartels 2005; Goyal et al. 2005; Mtwisha et al. 2006; Berjak et al. 2007; Chakrabortee et al. 2007; Tunnacliffe and Wise 2007; Farrant et al. 2012). All these functions can be visualized to be of relevance to maintenance of subcellular structural integrity in water-deprived environments and indeed in the ultimate promotion of metabolic quiescence in the dry state. Interestingly, there is also transcriptional upregulation of a rehydrin protein (RHXv) (Mundree and Farrant 2000), induced in response to rehydration of the desiccation-tolerant moss, Tortula ruralis (Oliver et al. 2005) and it is proposed that it has a dehydrin-like function, potentially protecting membranes and/or facilitating lipid transport for reconstitution of damaged membranes during rehydration.

Other gene products upregulated during LRD and which may play a role in maintenance of structural integrity during desiccation are XvSAP1, actin, several histones, GTP-binding proteins and oligosaccharide transferases (Mundree and Farrant 2000; Ingle et al. 2007; Abdalla and Rafudeen 2012). XvSAP1 in addition to being a putative signalling molecule (reviewed above) has been proposed by Garwe (2003) and Garwe et al. 2003 to be involved during the late stages of drying in ion homeostasis and membrane stabilization. Actin participates in more protein-protein interactions than any known protein and its ability to transition between monomeric (G-actin) and filamentous (F-actin) states under the control of nucleotide hydrolysis, ions, and a large number of actin-binding proteins, make it a critical component of many cellular functions, including maintenance of cell shape and polarity and the regulation of transcription (Dominguez and Holmes 2011). The precise role of increased actin during water deficit is unknown, but increased levels at low water contents, when transcription and translation processes are reduced, might suggest that along with increased GTPbinding proteins, actin is involved in processes associated with structural stabilization in the dry state. Increased expression of histone proteins (H2A.5, H3.2 and H4) is speculated to be involved in regulation of late gene expression and in protection and stabilization of DNA in the dry state (Abdalla and Rafudeen 2012). Oligosaccharide transferases serve as glycosylating agents and as such could play a number of roles during late stage dehydration, including stabilization of biopolymers (DNA, RNA and proteins) and/or in co- and post-translational modifications that facilitate tolerance of water deficits (Varki and Lowe 2009).

\section{Metabolite changes}

A common feature in plant desiccation tolerance is the accumulation during the late stages of drying of high amounts of sucrose and RFOs (reviewed in Berjak et al. 2007; Bartels and Hussain 2011; Farrant et al. 2012; Dinakar and Bartels 2013, Elsayed et al. 2014). In X. viscosa there is a 30- to 50-fold increase sucrose, a 25-fold increase in raffinose and stachyose and a tenfold increase in verbascose content, along with depletion of monosaccharides (glc and fru), galactinol and myo-inositol of leaves during the LRD (Whittaker et al. 2001; Peters et al. 2007; Farrant et al. 2007). Accompanying these changes there is an increase in transcript and protein levels of an isoform of sucrose synthase (XvSUS2) (Ngwarai 2014) and increased hexokinase (Whittaker et al. 2001), galactinol synthase (GolS; Peters et al. 2007) and myo-inositol 1-phosphate synthase (Lehner et al. 2008) activities in X. viscosa leaves during drying. We propose that accumulation of these particular sugars facilitate the formation non-crystalline glasses (Leopold and Vertucci 1986; Vertucci and Farrant 1995; Buitink et al. 2002; Berjak et al. 2007) while at the same time removing reducing sugars and aldoses that, in high quantities under water deficit conditions, can lead to formation of ROS via Maillard reactions (Walters et al. 2002). Other proposed roles for selective oligosaccharide accumulation during extreme water loss are replacement of water by substitution of $\mathrm{H}$ bonds lost during dehydration (Crowe and Crowe 1986; Crowe et al. 1989), as antioxidants (Van den Ende and Valluru 2009) and as sugar- 
sensors capable of regulating of gene expression under conditions of oxidative stress (reviewed in Rosa et al. 2009). Furthermore, oligosaccharides accumulated during drying are rapidly mobilized during rehydration, probably serving as an energy source for repair and recovery.

In addition to the reallocation of soluble sugars, a number of other primary metabolites are regulated in response to desiccation in the closely related Xerophyta humilis (Dace 2014), with preliminary data suggesting that $X$. viscosa behaves similarly. Specifically, the amino acids aspartic acid, glycine, phenylalanine, threonine, tryptophan and tyrosine increase in abundance during LRD. This is likely to be a consequence of protein degradation, resulting in pools of free amino acids necessary for early recovery. The pools of simple organic acids change substantially, with citric acid increasing while malic and succinic acids decreasing in abundance (Dace 2014). The change in organic acid profiles may contribute to the formation of ionic liquids that have been proposed to facilitate and maintain solubility of macromolecules in the absence of water (Choi et al. 2011).

The overall changes observed during late stages of dehydration are summarized in Fig. 5b. These changes are likely to not only facilitate tolerance of extreme water deficit, but also in preparation for reconstitution of metabolism on rehydration. Within the nucleus there is upregulation of histone-like proteins proposed to stabilize the DNA in the dry state and RNA-binding proteins that stabilize transcripts required for rehydration. Among these are likely to be transcripts required for regeneration of the photosynthetic machinery which is disassembled during drying. Interestingly, there is upregulation of an $\mathrm{FtsH}$ protease that has been purported to be involved in chloroplast biogenesis and photosystem II repair (Zaltsman et al. 2005; Ingle et al. 2007). Key metabolic changes occurring during LRD involve further shifts in carbon allocation towards specific primary metabolic pathways, including the synthesis of sucrose, RFOs, citric acid and various amino acids, with concomitant changes in enzymes associated with their anabolism. Many of these are probably accumulated in the numerous small vacuoles (inset Fig. 5b) facilitating mechanical stabilization in the dry state. Furthermore, such metabolites have been implicated in stabilization of the subcellular milieu by vitrification which can include glass- and ionic liquid formation.

\section{Biotechnological studies}

One of the aims of our research on X. viscosa is the development of crops with improved drought tolerance. As it is a monocot it could serve as a model for understanding what might be required for the production of drought- tolerant cereals. As outlined above, desiccation tolerance is a complex phenomenon involving the regulated expression of numerous genes, the products of which interact through chemical and physical processes to limit damage associated with water deficit and to facilitate survival in the dehydrated state. Most resurrection plants have a large genome and thus are difficult to transform, precluding genetic studies that might facilitate understanding of key regulators of desiccation tolerance. While it is unlikely that transformation of drought-sensitive species with only one or two genes will actually result in complete tolerance of water loss, such approaches have met with some improvement in drought tolerance (e.g. Xu et al. 2011; reviewed in Deikman et al. 2012). We are thus attempting to transform maize with some of the genes shown to be highly upregulated during drying in $X$. viscosa. The importance of the development of drought-tolerant maize for Africa is exemplified by the Water Efficient Maize for Africa (WEMA) project which is managed by the African Agricultural Technology Foundation (AATF; Oikeh et al. 2014).

We have shown previously that selected $X$. viscosa genes transformed into dicots such as $A$. thaliana and tobacco confers abiotic stress tolerance to these transgenic plants when exposed to a variety of abiotic stresses (Garwe et al. 2006; Govender 2006; Mundree et al. 2006; Maredza 2007; Kumar et al. 2013). Furthermore, we have used the stressinducible promoter of XvSap to drive the expression of reporter genes in $A$. thaliana, tobacco and maize tissue culture (Black Mexican sweetcorn) (Oduor 2009; Ellick 2012). The $X v S a p$ promoter is only induced upon abiotic stress treatments and could be useful in the future improvement of drought tolerance of crop plants, as it is known that the constitutive expression of genes involved in abiotic stress resistance can hamper the normal growth of transgenic plants (Morran et al. 2011). These results encouraged us to transform a combination of XvSap, XvPrx2 and $X v A l d$ into two inbred tropical CYMMIT maize lines, respectively, under the control of the XvSap promoter. Further work is underway to confirm transformation events prior to subjecting the transformants to water deficit stress.

\section{Concluding remarks}

With predictions that much of sub-Saharan Africa will be desertified by 2060 (Dai 2013), it is important that crops tolerant of extended hot and dry conditions be made available for African farmers. It is our premise that understanding of mechanisms, whereby tolerance of extreme water deficit is achieved will enable informed decisions of what would be required to improve tolerance (rather than just improved resistance characteristics) in annual crops of 
relevance to such farmers. The resurrection plant $X$. viscosa serves as a model for such understanding. DT is a complex phenomenon and is under the control of numerous interacting factors. In the absence of annotated genome sequence information for this (and any other resurrection plant species), we have used, and describe here, a systems approach in which physiological, biophysical, biochemical and molecular changes that accompany dehydration have been followed. The roles of these in overcoming the main stresses associated with ongoing water deficit (Walters et al. 2002) have been alluded to. While this approach has built a foundation for understanding key changes associated with DT, is has drawbacks, in that subtle but important changes may have been missed. This is due, in part, to the fact that analysis of omic data is reliant on statistical tools that by choice indicate only major changes in tissues at the various RWC analysed. Furthermore, our analysis fails to include nature and roles "orphan" genes/proteins/metabolites noted to change in abundance but the identity of which is as yet unknown. Future studies will include production of a high-quality reference genome for $X$. viscosa and a detailed analysis of tissue-specific transcription factors which regulate changes associated with survival of high levels of water deficit.

In the absence of such information to date, we have relied on data generated by studies reviewed here to select genes for transformation of maize, a staple crop in Africa. While such studies have yielded some evidence of improvement in drought tolerance, as has indeed been reported by other researchers who have attempted to improve this trait in various crops (reviewed in Deikman et al. 2012), they suffer from the drawbacks of trans generational instability and more importantly from the plasticity of a trait which is attained by only small effects generated by each of the genes included. The identification of key tissueassociated regulatory networks controlling DT should ultimately enable manipulated regulation of multiple pathways that are required for tolerance of extreme water loss.

Author contribution statement JMF initiated research on $X$. viscosa, was the PI of fundamental studies reported and wrote the bulk of the paper. KC compiled tables and figures and contributed to analyses of these data. AH assisted with compilation of molecular data and referencing. KOA conducted nuclear proteome studies. JB wrote the taxonomical aspects of the paper and compiled distribution map. JAT conceived and designed biotechnological studies. HJWD provided and gave input into metabolite data. NP contributed toward interpretation of gene expression data. SGM conceived and designed early transcriptome studies. MSR conceived nuclear proteome studies and was Co-PI of functional analyses of selected protein and gene studies reported. All authors read and edited the paper.
Acknowledgments The authors thank John and Sandy Burrow (Managers), and Elizabeth Parker (Owner) of Buffelskloof Nature Reserve, Mpumulanga, and the KwaZulu Natal Parks Board, for allowing plant collection. Research was funded by grants to JMF from the University of Cape Town, the National Research Foundation of South Africa and the Oppenheimer Foundation. JMF, SGM, JAT AND MSR also acknowledge and thank all the students we have supervised whose work we cite here.

Open Access This article is distributed under the terms of the Creative Commons Attribution 4.0 International License (http:// creativecommons.org/licenses/by/4.0/), which permits unrestricted use, distribution, and reproduction in any medium, provided you give appropriate credit to the original author(s) and the source, provide a link to the Creative Commons license, and indicate if changes were made.

\section{References}

Aalto MK, Helenius E, Kariola T, Pennanen V, Heino P, Hõrak H et al (2012) ERD15-an attenuator of plant ABA responses and stomatal aperture. Plant Sci 182:19-28

Abdalla KO, Rafudeen MS (2012) Analysis of the nuclear proteome of the resurrection plant Xerophyta viscosa in response to dehydration stress using iTRAQ with 2DLC and tandem mass spectrometry. J Proteomics 75:2361-2374

Abdalla KO, Baker B, Rafudeen MS (2010) Proteomic analysis of nuclear proteins during dehydration of the resurrection plant Xerophyta viscosa. Plant Growth Reg 62:279-292

Alamillo J, Almoguera C, Bartels D, Jordano J (1995) Constitutive expression of small heat shock proteins in vegetative tissues of the resurrection plant Craterostigma plantagineum. Plant Mol Biol 29:1093-1099

Alpert P, Oliver MJ (2002) Drying without dying. In: Black M, Pritchard $\mathrm{H}$ (eds) Desiccation and survival in plants: drying without dying. CABI Publishing, Wallingford, pp 3-46

Apel K, Hirt H (2004) Reactive oxygen species: metabolism, oxidative stress, and signal transduction. Annu Rev Plant Biol 55:373-399

Ascenzi R, Gantt JS (1997) A drought-stress-inducible histone gene in Arabidopsis thaliana is a member of a distinct class of plant linker histone variants. Plant Mol Biol 34:629-641

Bartels D (2005) Desiccation tolerance studied in the resurrection plant Craterostigma plantagineum. Integ Comp Biol 45:696-701

Bartels D, Hussain SS (2011) Resurrection plants: physiology and molecular biology. In: Lüttge U, Beck E, Bartels D (eds) Plant desiccation tolerance. Springer, Berlin, pp 339-364

Behnke H-D (2002) Sieve-element plastids and evolution of monocotyledons, with emphasis on Melanthiaceae sensu lato and Aristolochiaceae-Asaroideae, a putative dicotyledon sister group. Bot Rev 68:524-544

Behnke H-D, Treutlein J, Wink M, Kramer K, Schneider C, Kao PC (2000) Systematics and evolution of Velloziaceae, with special reference to sieve-element plastids and rbcL sequence data. Bot J Linn Soc 134:93-129

Behnke H-D, Hummel E, Hillmer S, Sauer-Gürth H, Gonzalez J, Wink M et al (2013) A revision of African Velloziaceae based on leaf anatomy characters and rbcL nucleotide sequences. Bot $\mathrm{J}$ Linn Soc 172:22-94

Belton PS (1997) NMR and the mobility of water in polysaccharide gels. Int J Biol Macromol 21:81-88

Berjak P, Farrant JM, Pammenter NW (2007) Seed desiccationtolerance mechanisms. In: Jenks MA, Wood AJ (eds) Plant desiccation tolerance. Blackwell Publishing, Ames, pp 151-192 
Bewley JD, Reynolds TL, Oliver MJ (1993) Evolving strategies in the adaptation to desiccation. In: Close TJ, Bray EA (eds) Plant responses to cellular dehydration during environmental stress. University of California Press, Riverside, pp 193-201

Bhatt A, Naidoo Y, Gairola S, Nicholas A (2009) Ultrastructural responses of the desiccation tolerant plants Xerophyta viscosa and $X$. retinervis to dehydration and rehydration. Biol Plant 53:373-377

Bohen SP, Yamamoto KR (1994) Modulation of steroid receptor signal transduction by heat shock proteins. Cold Spring Harbor Monogr Arch 26:313-334

Bray E (1997) Plant responses to water deficit. Trends Plant Sci 2:48-54

Bresler AP (2010) Molecular characterisation of XvVTC2, a gene coding for a GDP-K-galactose phosphorylase from Xerophyta viscosa. Thesis, University of Cape Town

Buchner J (1999) Hsp90 \& Co.-a holding for folding. Trends Biochem Sci 24:136-141

Buitink J, Hoekstra FA, Leprince O (2002) In: Black M, Pritchard H (eds) Desiccation and survival in plants: drying without dying. CABI Publishing, Wallingford, pp 293-318

Buitink J, Leger JJ, Guisle I, Vu BL, Wuillème S, Lamirault G et al (2006) Transcriptome profiling uncovers metabolic and regulatory processes occurring during the transition from desiccationsensitive to desiccation-tolerant stages in Medicago truncatula seeds. Plant J 47:735-750

Carbutt C, Edwards TJ (2006) The endemic and near-endemic angiosperms of the Drakensberg Alpine Centre. S Afr JBot $72: 105-132$

Chakrabortee S, Boschetti C, Walton LJ, Sarkar S, Rubinsztein DC, Tunnacliffe A (2007) Hydrophilic protein associated with desiccation tolerance exhibits broad protein stabilization function. Proc Natl Acad Sci USA 104:18073-18078

Charuvi D, Nevo R, Shimoni E et al (2015) Photoprotection conferred by changes in photosynthetic protein levels and organization during dehydration of a homoiochlorophyllous resurrection plant. Plant Physiol 167:1554-1565

Chinnusamy V, Zhu J-K (2009) Epigenetic regulation of stress responses in plants. Curr Opin Plant Biol 12:133-139

Choi YH, van Spronsen J, Dai Y, Verberne M, Hollmann F, Arends IWCE et al (2011) Are natural deep eutectic solvents the missing link in understanding cellular metabolism and physiology? Plant Physiol 156:1701-1705

Christ B, Süssenbacher I, Moser S, Bichsel N, Egert A, Müller T et al (2013) Cytochrome P450 CYP89A9 is involved in the formation of major chlorophyll catabolites during leaf senescence in Arabidopsis. Plant Cell 25:1868-1880

Close TJ (1997) Dehydrins: a commonalty in the response of plants to dehydration and low temperature. Physiol Plant 100:291-296

Coetzee H (1974) Anatomy of the leaves of the Velloziaceae in the South Africa and southwest Africa a key based on leaf anatomy. Dissertation, University of Pretoria

Coetzee H, Van der Schijff HP (1973) New combinations in Xerophyta Juss. (Vellozia Vand. pro parte). SA J Bot 39:269

Collett H, Butowt R, Smith J, Farrant J, Illing N (2003) Photosynthetic genes are differentially transcribed during the dehydrationrehydration cycle in the resurrection plant, Xerophyta humilis. J Exp Bot 54:2593-2595

Collett H, Shen A, Gardner M, Farrant JM, Denby KJ, Illing N (2004) Towards transcript profiling of desiccation tolerance in Xerophyta humilis: construction of a normalized $11 \mathrm{k} \mathrm{X}$. humilis cDNA set and microarray expression analysis of 424 cDNAs in response to dehydration. Physiol Plant 122:39-53

Conrad N (2005) Characterization of XVEF and XvCam, two calcium-binding proteins isolated from the resurrection plant Xerophyta viscosa. Dissertation, University of Cape Town
Crowe JH, Crowe LM (1986) Stabilization of membranes in anhydrobiotic organisms. In: Leopold AC (ed) Membranes, metabolism and dry organisms. Comstock Publ. Associates, Ithaca, pp 188-209

Crowe JH, Crowe LM, Hoekstra FA (1989) Phase transitions and permeability changes in dry membranes during rehydration. J Bioenerg Biomembr 21:77-91

Cuming AC (1999) LEA proteins. In: Shewry PR, Case R (eds) Seed proteins. Springer, Netherlands, pp 753-780

Dace H (2014) The metabolomics of desiccation tolerance in Xerophyta humilis. Thesis, University of Cape Town

Dace H, Sherwin HW, Illing N, Farrant JM (1998) Use of metabolic inhibitors to elucidate mechanisms of recovery from desiccation stress in the resurrection plant Xerophyta humilis. Plant Growth Reg 24:171-177

Dai A (2013) Increasing drought under global warming in observations and models. Nat Clim Change 3:52-58

Davis E (2005) Molecular characterization of ALDRXv4, an aldose reductase orthologue isolated from Xerophyta viscosa, in response to abiotic stress. M.Sc. Thesis, University of Cape Town

Deikman J, Petracek M, Heard JE (2012) Drought tolerance through biotechnology: improving translation from the laboratory to farmers' fields. Curr Opin Biotech 23:243-250

Dietz K-J (2011) Peroxiredoxins in plants and cyanobacteria. Antioxid Redox Signal 15:1129-1159

Dinakar C, Bartels D (2013) Desiccation tolerance in resurrection plants: new insights from transcriptome, proteome and metabolome analysis. Front Plant Sci 4:482

Dinakar C, Djilianov D, Bartels D (2012) Photosynthesis in desiccation tolerant plants: energy metabolism and antioxidative stress defense. Plant Sci 182:29-41

Dominguez R, Holmes KC (2011) Actin structure and function. Annu Rev Biophys 40:169-186

Ellick TL (2012) Investigation of XvSap promoters from the resurrection plant, Xerophyta viscosa. Dissertation, University of Cape Town

Elsayed AI, Rafudeen MS, Golldack D (2014) Physiological aspects of raffinose family oligosaccharides in plants: protection against abiotic stress. Plant Biol 16:1-8

Farrant JM, Brandt W, Lindsey GG (2007) An overview of mechanisms of desiccation tolerance in selected angiosperm resurrection plants. Plant Stress 1:72-84

Farrant JM, Cooper K, Nell H (2012) Desiccation tolerance. In: Shabala S (ed) Plant stress physiology. CABI Publishing, Cambridge, pp 238-265

Foster TJ, Ablett S (1996) Mobility-resolved I3C-NMR. Biopolymers 39:1-66

Foyer CH (2010) Mitochondrial redox state, nitrogen metabolism and signalling. Annu Plant Rev 42:287-304

Foyer CH, Noctor G (2005) Redox homeostasis and antioxidant signaling: a metabolic interface between stress perception and physiological responses. Plant Cell 17:1866-1875

Foyer CH, Noctor G (2009) Redox regulation in photosynthetic organisms: signaling, acclimation, and practical implications. Antioxid Redox Signal 11:861-905

Foyer CH, Harbinson J, Mullineaux PM et al (1994) Oxygen metabolism and the regulation of photosynthetic electron transport. In: Foyer $\mathrm{CH}$, Mullineaux PM (eds) Causes of photooxidative stress and amelioration of defense systems in plants. CRC Press Inc, Boca Raton, pp 1-42

Gaff DF (1977) Desiccation tolerant vascular plants of Southern Africa. Oecology 3:95-109

Gaff DF, Oliver M (2013) The evolution of desiccation tolerance in angiosperm plants: a rare yet common phenomenon. Funct Plant Biol 40:315-328 
Garwe D (2003) Molecular characterization of XVSAP1, a stressresponsive gene from the resurrection plant Xerophyta viscosa Baker. Dissertation, University of Cape Town

Garwe D, Thomson JA, Mundree SG (2003) Molecular characterization of XVSAP1, a stress-responsive gene from the resurrection plant Xerophyta viscosa Baker. J Exp Bot 54:191-201

Garwe D, Thomson JA, Mundree SG (2006) XVSAP1 from Xerophyta viscosa improves osmotic-, salinity-and high-temperature-stress tolerance in Arabidopsis. Biotechnol $\mathrm{J}$ $1: 1137-1146$

Goldberg R, Morvan C, du Penhoat CH, Michon V (1989) Structure and properties of acidic polysaccharides from mung bean hypocotyls. Plant Cell Physiol 30:163-173

Gosti F, Beaudoin N, Serizet C, Webb AAR, Vartanian N, Giraudat J (1999) ABI1 protein phosphatase $2 \mathrm{C}$ is a negative regulator of abscisic acid signaling. Plant Cell 11:1897-1909

Govender K (2006) Molecular and biochemical characterisation of a type II peroxiredoxin (XvPrx2) from the resurrection plant Xerophyta viscosa (Baker). Dissertation, University of Cape Town

Goyal K, Walton LJ, Browne JA, Burnell AM, Tunnacliffe A (2005) Molecular anhydrobiology: identifying molecules implicated in invertebrate anhydrobiosis. Integr Comp Biol 45:702-709

Halliwell B, Gutteridge JMC (1999) Free radicals in biology and medicine, 3rd edn. Oxford University Press, Oxford

Hirschi KD (2004) The calcium conundrum. Both versatile nutrient and specific signal. Plant Physiol 136:2438-2442

Hoekstra FA, Golovina EA, Buitink J (2001) Mechanisms of plant desiccation tolerance. Trends Plant Sci 6:431-438

Höfler K, Migsch H, Rottenburg W (1941) Über die Austrocknungresistenz landwirtschaftlicher Kulturpflanzen. Forschungsdienst Organ Deutsch. Landwirtschaftswiss 12:50-61

Holiday JC (2007) Characterisation of the potentially drought induced H1 variant found in Xerophyta viscosa. Hons Thesis, University of Cape Town

Iljin W (1957) Drought resistance in plants and physiological processes. Annu Rev Plant Physiol 8:257-274

Illing N, Denby KJ, Collett H, Shen A, Farrant JM (2005) The signature of seeds in resurrection plants: a molecular and physiological comparison of desiccation tolerance in seeds and vegetative tissues. Integ Comp Biol 45:771-787

Ingle RA, Schmidt UG, Farrant JM, Thomson JA, Mundree SG (2007) Proteomic analysis of leaf proteins during dehydration of the resurrection plant Xerophyta viscosa. Plant Cell Environ 30:435-446

Ingle RA, Collett H, Cooper K, Takahashi Y, Farrant JM, Illing N (2008) Chloroplast biogenesis during rehydration of the resurrection plant Xerophyta humilis: parallels to the etioplastchloroplast transition. Plant Cell Environ 31:1813-1824

Ingram J, Bartels D (1996) The molecular basis of dehydration tolerance in plants. Annu Rev Plant Biol 47:377-403

Iyer R, Mundree SG, Rafudeen MS, Thomson JA (2008) XvSap1, a desiccation tolerance associated gene with potential for crop improvement. In: Jenks MA, Wood AJ (eds) Plant desiccation tolerance. Wiley, Oxford, pp 283-296

Kamies R (2011) A methodological investigation into the roots of the resurrection plant, Xerophyta viscosa, for further proteomic analyses. University of Cape Town, Thesis

Kamies R, Rafudeen MS, Farrant J (2010) The use of aeroponics to investigate antioxidant activity in the roots of Xerophyta viscosa. Plant Growth Reg 62:203-211

Kariola T, Brader G, Helenius E, Li J, Heino P, Palva ET (2006) Early response to dehydration, a negative regulator of abscisic acid responses in Arabidopsis. Plant Physiol 142:1559-1573

Kim J-M, To TK, Nishioka T, Seki M (2010) Chromatin regulation functions in plant abiotic stress responses. Plant Cell Environ 33:604-611
Kiyosue T, Yamaguchi-Shinozaki K, Shinozaki K (1994) Cloning of cDNAs for genes that are early-responsive to dehydration stress (ERDs) in Arabidopsis thaliana L.: identification of three ERDs as HSP cognate genes. Plant Mol Biol 25:791-798

Kranner I, Birtić S (2005) A modulating role for antioxidants in desiccation tolerance. Integ Comp Biol 45:734-740

Kumar D, Singh P, Yusuf MA et al (2013) The Xerophyta viscosa aldose reductase (ALDRXV4) confers enhanced drought and salinity tolerance to transgenic tobacco plants by scavenging methylglyoxal and reducing the membrane damage. Mol Biotechnol 54:292-303

Lee M-Y (2005) XvERD15, an early-responsive gene to stress from Xerophyta viscosa. Dissertation, University of Cape Town

Lehner A, Chopera DR, Peters SW, Keller F, Mundree SG, Thomson JA et al (2008) Protection mechanisms in the resurrection plant Xerophyta viscosa: cloning, expression, characterisation and role of XvINO1, a gene coding for a myo-inositol 1-phosphate synthase. Funct Plant Biol 35:26-39

Leopold AC, Vertucci CW (1986) Physical attributes of desiccated seeds. In: Leopold AC (ed) Membranes, metabolism and dry organisms. Cornell University Press, New York, pp 22-34

Leprince O, Buitink J (2010) Desiccation tolerance: from genomics to the field. Plant Sci 179:554-564

Leubner-Metzger G (2005) $\beta$-1, 3-Glucanase gene expression in lowhydrated seeds as a mechanism for dormancy release during tobacco after-ripening. Plant J 41:133-145

Marais S, Thomson JA, Farrant JM, Mundree SG (2004) XvVHA-c 1-a novel stress-responsive V-ATPase subunit $\mathrm{c}$ homologue isolated from the resurrection plant Xerophyta viscosa. Physiol Plant 122:54-61

Maredza AT (2007) Isolation of the aldose reductase gene (XvAld1) from the resurrection plant Xerophyta viscosa, and characterisation of the gene product and transgenic plants expressing the gene. Dissertation, University of Cape Town

McAinsh MR, Hetherington AM (1998) Encoding specificity in $\mathrm{Ca}^{2+}$ signalling systems. Trends Plant Sci 3:32-36

Mello-Silva R, Santos DYAC, Salatino MLF, Motta LB, Cattai MB, Sasaki D et al (2011) Five vicarious genera from Gondwana: the Velloziaceae as shown by molecules and morphology. Ann Bot 108:87-102

Moore JP, Le NT, Brandt WF, Driouich A, Farrant JM (2009) Towards a systems-based understanding of plant desiccation tolerance. Trends Plant Sci 14:110-117

Moore JP, Nguema-Ona EE, Vicré-Gibouin M, Sørensen I, Willats WGT, Driouich A et al (2013) Arabinose-rich polymers as an evolutionary strategy to plasticize resurrection plant cell walls against desiccation. Planta 237:739-754

Morran S, Eini O, Pyvovarenko T, Parent B, Singh R, Ismagul A et al (2011) Improvement of stress tolerance of wheat and barley by modulation of expression of DREB/CBF factors. Plant Biotechnol J 9:230-249

Mowla SB, Thomson JA, Farrant JM, Mundree SG (2002) A novel stress-inducible antioxidant enzyme identified from the resurrection plant Xerophyta viscosa Baker. Planta 215:716-726

Mtwisha L, Farrant J, Brandt W et al (2006) Protection mechanisms against water deficit stress: desiccation tolerance in seeds as a study case. In: Ribaut JM (ed) Drought adaptation in cereals. The Haworth Press, New York, pp 531-549

Mucina L, Rutherford MC (eds) (2006) The vegetation of South Africa, Lesotho and Swaziland. South African National Biodiversity Institute, Pretoria

Mundree SG, Farrant JM (2000) Some physiological and molecular insights into the mechanisms of desiccation tolerance in the resurrection plant Xerophyta viscosa Baker. In: Cherry JH (ed) Plant tolerance to abiotic stress in agriculture: Role of genetic engineering. Kluwer Academic Publishers, Dordrecht, pp 201-222 
Mundree SG, Baker B, Mowla S, Peters S, Marais S, Vander Willigen C, Govender K, Maredza A, Farrant JM, Thomson JA (2002) Physiological and molecular insights into drought tolerance. Afr J Biotech 1:28-38

Mundree SG, Iyer R, Baker B et al (2006) Prospects for using genetic modification to engineer drought tolerance in crops. In: Halford NG (ed) Plant biotechnology: current and future applications of genetically modified crops. Wiley, Hoboken, pp 193-205

Naidoo G, Kaliamoorthy S, Naidoo Y (2009) The secretory apparatus of Xerophyta viscosa (Velloziaceae): epidermis anatomy and chemical composition of the secretory product. Flora-morphology, distribution. Funct Ecol Plants 204:561-568

Nakaminami K, Matsui A, Shinozaki K, Seki M (2012) RNA regulation in plant abiotic stress responses. Biochim Biophys Acta 1819:149-153

Ndima T, Farrant J, Thomson J, Mundree S (2001) Molecular characterization of $X V T 8$, a stress-responsive gene from the resurrection plant Xerophyta viscosa Baker. Plant Growth Reg 35:137-145

Ngwarai MR (2014) Isolation and characterisation of a sucrose synthase gene from Xerophyta viscosa. Honours Thesis, University of Cape Town

Oduor OR (2009) Functional analysis of the novel stress-inducible XVPSAP promoter isolated from Xerophyta viscosa. Dissertation, University of Cape Town

Oikeh S, Ngonyamo-Majee D, Mugo SN et al (2014) The water efficient maize for Africa project as an example of a publicprivate partnership. In: Songstad DD, Hatfield JL, Tomes DT (eds) Convergence of food security, energy security and sustainable agriculture. Springer, Berlin, pp 317-329

Oliver MJ, Velten J, Mishler BD (2005) Desiccation tolerance in bryophytes: a reflection of the primitive strategy for plant survival in dehydrating habitats? Integ Comp Biol 45:788-799

Oracz K, Bouteau HE-M, Farrant JM, Cooper K, Belghazi M, Job C et al (2007) ROS production and protein oxidation as a novel mechanism for seed dormancy alleviation. Plant J 50:452-465

Peters S, Mundree SG, Thomson JA, Farrant JM, Keller F (2007) Protection mechanisms in the resurrection plant Xerophyta viscosa (Baker): both sucrose and raffinose family oligosaccharides (RFOs) accumulate in leaves in response to water deficit. J Exp Bot 58:1947-1956

Picard D, Khursheed B, Garabedian MJ et al (1990) Reduced levels of hsp90 compromise steroid receptor action in vivo. Nature 348:166-168

Pittman JK, Hirschi KD (2003) Don't shoot the (second) messenger: endomembrane transporters and binding proteins modulate cytosolic $\mathrm{Ca}^{2+}$ levels. Curr Opin Plant Biol 6:257-262

Porembski S, Barthlott W (2000) Granitic and gneissic outcrops (inselbergs) as centers of diversity for desiccation-tolerant vascular plants. Plant Ecol 1931:19-28

Priestly DA (1986) Seed aging: Implications for seed storage and persistence in soil. Cornell University Press, Ithaca

Renard CMGC, Jarvis MC (1999) A cross-polarization, magic-anglespinning, 13C-nuclear-magnetic-resonance study of polysaccharides in sugar beet cell walls. Plant Physiol 119:1315-1322

Rosa M, Prado C, Podazza G, Interdonato R, González JA, Hilal M et al (2009) Soluble sugars-metabolism, sensing and abiotic stress. Plant Signal Behav 4:388-393

Sahu PP, Pandey G, Sharma N, Puranik S, Muthamilarasan M, Prasad $M$ (2013) Epigenetic mechanisms of plant stress responses and adaptation. Plant Cell Rep 32:1151-1159

Scippa GS, Griffiths A, Chiatante D, Bray EA (2000) The H1 histone variant of tomato, H1-S, is targeted to the nucleus and accumulates in chromatin in response to water-deficit stress. Planta 211:173-181
Seel W, Baker N, Lee J (1992) Analysis of the decrease in photosynthesis on desiccation of mosses from xeric and hydric environments. Physiol Plant 86:451-458

Sherwin HW, Farrant JM (1996) Differences in rehydration of three desiccation-tolerant angiosperm species. Ann Bot 78:703-710

Sherwin HW, Farrant JM (1998) Protection mechanisms against excess light in the resurrection plants Craterostigma wilmsii and Xerophyta viscosa. Plant Growth Reg 24:203-210

Smirnoff N (1993) Tansley Review No. 52. The role of active oxygen in the response of plants to water deficit and desiccation. New Phytol 125:27-58

Smirnoff N (ed) (2008) Antioxidants and reactive oxygen species in plants. Blackwell Publishing Ltd, Oxford

Sun WQ, Leopold AC (1995) The Maillard reaction and oxidative stress during aging of soybean seeds. Physiol Plant 94:94-104

Tunnacliffe A, Wise MJ (2007) The continuing conundrum of the LEA proteins. Naturwissenschaften 94:791-812

Tunnacliffe A, Hincha DK, Leprince O, Macherel D (2010) LEA proteins: Versitility of form and function. In: Lubzens E (ed) Dormancy and resistance in harsh environments. Springer, Berlin, pp 91-108

Umezawa T, Sugiyama N, Mizoguchi M, Hayashi S, Myouga F, Yamaguchi-Shinozaki K et al (2009) Type 2C protein phosphatases directly regulate abscisic acid-activated protein kinases in Arabidopsis. Proc Natl Acad Sci 106:17588-17593

Van den Ende W, Valluru R (2009) Sucrose, sucrosyl oligosaccharides, and oxidative stress: scavenging and salvaging? J Exp Bot 60:9-18

Van der Willigen C, Pammenter NW, Mundree SG, Farrant JM (2001) Some Physiological comparisons between the resurrection grass, Eragrostis nindensis, and the related desiccationsensitive species, Eragrostis curvula. Plant Growth Reg 35:121-129

Varki A, Lowe JB (2009) Biological roles of glycans. In: Varki A, Cummings RD, Esko JD, Freeze HH, Stanley P et al (eds) Essentials of glycobiology, 2nd edn. Cold Spring Harbor Laboratory Press, Cold Spring Harbor, pp 1-10

Vertucci C, Farrant J (1995) Acquisition and loss of desiccation tolerance. In: Kigel J, Galili G (eds) Seed development and germination. Marcel Dekker, New York, pp 237-270

Vicré M, Sherwin HW, Driouich A, Jaffer MA, Farrant JM (1999) Cell wall characteristics and structure of hydrated and dry leaves of the resurrection plant Craterostigma wilmsii, a microscopical study. J Plant Physiol 155:719-726

Vicré M, Lerouxel O, Farrant $\mathrm{J}$ et al (2004) Composition and desiccation-induced alterations of the cell wall in the resurrection plant Craterostigma wilmsii. Physiol Plant 120:229-239

Vierling E (1991) The roles of heat shock proteins in plants. Annu Rev of Plant Biol 42:579-620

Walford SA (2008) Activation of seed-specific genes in leaves and roots of the desiccation tolerant plant, Xerophyta humilis. Dissertation, University of Cape Town

Walford SA, Thomson JA, Farrant JM, Mundree SG et al (2003) The HSP90 family of chaperones: a look at the structure, function and mode of action. Curr Top Plant Biol 4:1-25

Walters C, Farrant JM, Pammenter NW, Berjak P (2002) Desiccation stress and damage. In: Black M, Pritchard H (eds) Desiccation and survival in plants: drying without dying. CABI Publishing, Wallingford, pp 263-291

Wang L, Shang H, Liu Y, Zheng M, Wu R, Phillips J et al (2009) A role for a cell wall localized glycine-rich protein in dehydration and rehydration of the resurrection plant Boea hygrometrica. Plant Biol 11:837-848

Wang W, Wang Y, Du Y, Zhao Z, Zhu X, Jiang X et al (2014) Overexpression of Camellia sinensis $\mathrm{H} 1$ histone gene confers 
abiotic stress tolerance in transgenic tobacco. Plant Cell Rep 33:1829-1841

Wehmeyer N, Hernandez LD, Finkelstein RR, Vierling E (1996) Synthesis of small heat-shock proteins is part of the developmental program of late seed maturation. Plant Physiol 112:747-757

Wei T, O'Connell M (1996) Structure and characterization of a putative drought-inducible $\mathrm{H} 1$ histone gene. Plant Mol Biol 30:255-268

Whittaker A, Bochicchio A, Vazzana C, Lindsey G, Farrant JM (2001) Changes in leaf hexokinase activity and metabolite levels in response to drying in the desiccation-tolerant species Sporobolus stapfianus and Xerophyta viscosa. J Exp Bot 52:961-969
Wise MJ, Tunnacliffe A (2004) POPP the question: what do LEA proteins do? Trends Plant Sci 9:13-17

Xu G-Y, Rocha PSCF, Wang M-L, Xu M-L, Cui Y-C, Li L-Y et al (2011) A novel rice calmodulin-like gene, OsMSR2, enhances drought and salt tolerance and increases ABA sensitivity in Arabidopsis. Planta 234:47-59

Zaltsman A, Ori N, Adam Z (2005) Two types of FtsH protease subunits are required for chloroplast biogenesis and photosystem II repair in Arabidopsis. Plant Cell 17:2782-2790 